\title{
Biogeochemical Research Priorities for Sustainable Biofuel and Bioenergy Feedstock Production in the Americas
}

\author{
Hero T. Gollany ${ }^{1}$ (D) Brian D. Titus ${ }^{2} \cdot$ D. Andrew $\operatorname{Scott}^{3} \cdot$ Heidi Asbjornsen ${ }^{4}$. \\ Sigrid C. Resh ${ }^{5}$ Rodney A. Chimner ${ }^{5}$ - Donald J. Kaczmarek ${ }^{6}$ Luiz F. C. Leite ${ }^{7}$. \\ Ana C. C. Ferreira ${ }^{8} \cdot{\text { Kenton A. } \text { Rod }^{9} \cdot \text { Jorge Hilbert }^{10} \cdot \text { Marcelo V. Galdos }}^{11}$. \\ Michelle E. Cisz ${ }^{5}$
}

Received: 27 June 2014/ Accepted: 4 May 2015

(C) Springer Science+Business Media New York (outside the USA) 2015

\begin{abstract}
Rapid expansion in biomass production for biofuels and bioenergy in the Americas is increasing demand on the ecosystem resources required to sustain soil and site productivity. We review the current state of knowledge and highlight gaps in research on biogeochemical processes and ecosystem sustainability related to biomass production. Biomass production systems incrementally remove greater quantities of organic matter, which in turn affects soil organic matter and associated carbon and nutrient storage (and hence long-term soil productivity) and off-site impacts. While these consequences have been extensively studied for some crops and sites, the ongoing and impending impacts of biomass removal require management strategies for ensuring that soil properties and functions are sustained for all combinations of crops, soils, sites, climates, and management systems, and that impacts of biomass management (including off-site impacts)
\end{abstract}

Hero T. Gollany

hero.gollany@ars.usda.gov

1 Columbia Plateau Conservation Research Center, USDAAgricultural Research Service, 48037 Tubbs Ranch Road, Adams, OR 97810, USA

2 Natural Resources Canada, Canadian Forest Service, Pacific Forestry Centre, 506 West Burnside Rd., Victoria, BC V8Z 1M5, Canada

3 USDA Forest Service, Southern Research Station, Agricultural Research Center, 4900 Meridian Street, Normal, AL 35762, USA

4 Department of Natural Resources and the Environment and the Earth Systems Research Center, Institute for Earth, Oceans and Space, University of New Hampshire, Durham, NH 03824, USA

5 School of Forest Resources and Environmental Science, Michigan Technological University, 1400 Townsend Drive, Houghton, MI 49931, USA are environmentally acceptable. In a changing global environment, knowledge of cumulative impacts will also become increasingly important. Long-term experiments are essential for key crops, soils, and management systems because short-term results do not necessarily reflect long-term impacts, although improved modeling capability may help to predict these impacts. Identification and validation of soil sustainability indicators for both site prescriptions and spatial applications would better inform commercial and policy decisions. In an increasingly interrelated but constrained global context, researchers should engage across inter-disciplinary, inter-agency, and international lines to better ensure the long-term soil productivity across a range of scales, from site to landscape.

Keywords Agroecosystem - Bioenergy feedstock · Carbon $\cdot$ Forestry $\cdot$ Soil $\cdot$ Sustainability

6 Oregon Department of Forestry, 3700 Mahony Road, St. Paul, OR 97137, USA

7 Empresa Brasileira de Pesquisa Agropecuária (EMBRAPA), Teresina, PI 64006-220, Brazil

8 Climate Change Adaptation Consultant, R. $21 \mathrm{Sul} \mathrm{Lt}$ 09/1004, Taguatinga 71925-540, Brazil

9 School of the Environment, Washington State University, Pullman, WA 99164, USA

10 Centro de Investigaciónes de Agroindustria (CIA), Instituto Nacional de Tecnologia agropecuaria (INTA),

C.C. 25, Castelar 1712, Prov. de Buenos Aires, Argentina

11 Brazilian Bioethanol Science and Technology Laboratory (CTBE), Brazilian Center for Research in Energy and Materials (CNPEM), Campinas, SP 13083-100, Brazil 


\section{Introduction}

Renewable energy is increasingly used as an alternative to fossil fuels, with production rising steadily over the past 30 years (IPCC 2011; Chum et al. 2011). Approximately $10 \%\left(50.3 \mathrm{EJ} ; \mathrm{EJ}=10^{18} \mathrm{~J}\right)$ of the world's primary energy supply (492 EJ) came from renewable sources in 2008, mostly from traditional fuelwood $(\sim 25 \mathrm{EJ})$ and from modern bioenergy ( 15 EJ) (IPCC 2011; Chum et al. 2011). Bioenergy can be derived from a range of feedstocks, including grains, seeds, and cellulosic biomass (IPCC 2011). Feedstocks can be by- or co-products of traditional agricultural and forestry products or can come from dedicated biomass crops (e.g., Miscanthus, willow). Feedstock production for bioenergy also typically takes place within a larger system of land management for food, feed and/or fiber within the landscape.

Bioenergy is part of the solution to global energy, climate, and ecological challenges (Achten et al. 2012) but must be environmentally, socially, and economically sustainable (World Commission on Environment and Development 1987) if its benefits are to be fully realized. However, questions have been raised about the extent to which increased production will be environmentally sustainable (Lal 2005, 2007) because increased demand on finite soil resources for food, feed, fiber, and fuel for the world's growing population can exacerbate environmental problems, including soil degradation.

Soil is a fundamental natural resource that influences nutrient cycling, terrestrial carbon (C) sequestration, and the hydrologic cycle (Brady and Weil 2007; Binkley and Fisher 2013). Identifying processes, practices, and policies for sustainable management of soil resources for biomass production is critical because unsustainable production can be catastrophic in extreme cases, as exemplified by the collapse of the Sumerian civilization of ancient Mesopotamia and the "Dust Bowl" in the US during the 1930s (Lowdermilk 1953; Troeh et al. 1980). While physical loss of soil through erosion is an obvious problem, crop residue (straw and stover) removal from agricultural fields can reduce crop yield (Blanco-Canqui and Lal 2009a, b; Malhi and Lemke 2007; Miner et al. 2013; Wilhelm et al. 2004; Wilts et al. 2004). Similarly, it has been known in forestry for over 100 years that organic matter (OM) removal through litter raking under trees (for animal bedding) can reduce tree growth (Ebermayer 1876 in Johnson 1994), and modern harvesting (residue removal) from forests for bioenergy can lead to reduced growth on some sites (Scott and Dean 2006; Gonçalves et al. 2008).

Sustainable soil management is essential if bioenergy derived from biomass is to be an acceptable alternative to fossil fuels, regardless of the crop, management practices, and harvesting intensities. Exchange of knowledge and experience can enhance soil sustainability but is often westeast across the Atlantic Ocean, rather than north-south; for example, recent reviews on impacts of harvesting forest residue by North Americans and Europeans (Thiffault et al. 2011; Wall 2012) have not included information from the southern hemisphere. However, Pan-American countries in both hemispheres produce large amounts of liquid and solid biofuels (Janssen and Rutz 2011; Lamers et al. 2012; REN21 2014; Rutz et al. 2010), and this is predicted to increase. Geographical north-south connectedness, evolving free-trade agreements between Pan-American countries, and the potential for export- as well as domestic-oriented biofuel development suggests that sharing knowledge and experience in bioenergy production, including research on and implementation of the most sustainable soil management practices, will benefit the Americas.

Developing effective collaborative research strategies requires a clear understanding of the greatest research needs. A review of the literature was therefore completed for a spectrum of biomass feedstock sources from agricultural, forestry, agroforestry, and short-rotation woody crops (SRWC), focusing on (1) management systems in which increased biomass harvesting for energy production is incremental to traditional practices and (2) dedicated biomass crops. This information was used to identify key biogeochemical cycling knowledge gaps that need to be addressed to ensure sustainable management of soils in bioenergy feedstock production systems in the Americas.

\section{Geographical Context}

The Americas encompass extreme contrasts, from the Arctic, south through the tropics, to the sub-Antarctic. A wide range of soils, landforms, and climates are found within this vast area, including all $28 \mathrm{FAO} / \mathrm{UNESCO}$ soil orders (Fig. 1; Batjes 2009) and most of the global climate zones (Fig. 2).

\section{Feedstock Types}

A range of species can be grown or managed to produce biomass feedstocks. Biomass can be harvested from agricultural and forest systems as either a co-product of harvesting or the sole product.

\section{Agriculture}

Agricultural production of biomass feedstocks ranges from increased use of traditionally unharvested plant matter (e.g., 
Fig. 1 Soil distribution in the Pan-American region (FAOUNESCO 2007). (Reproduced with permission of FAOUNESCO)

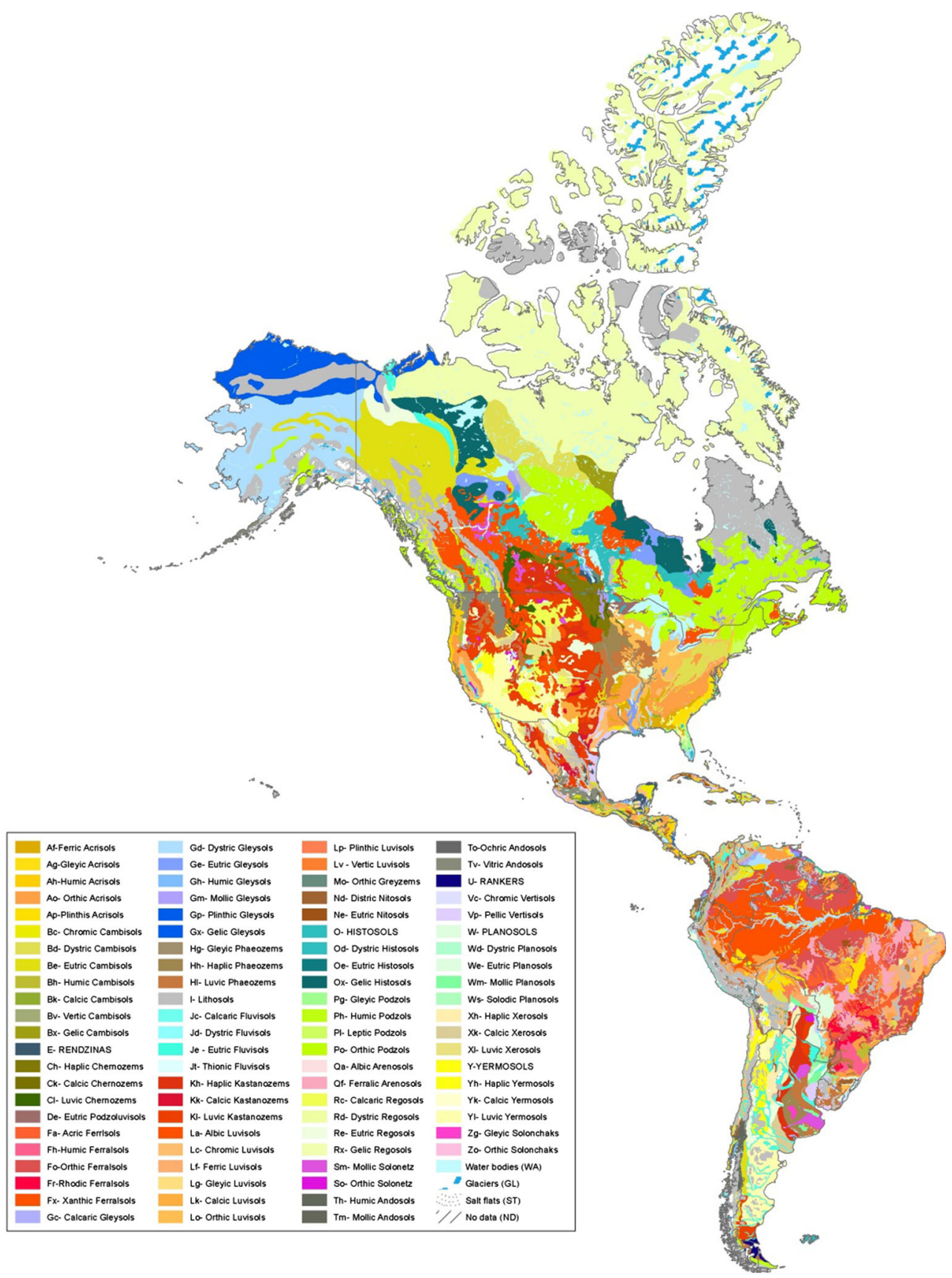

stover and bagasse) to new management systems for perennial grasses. Both types of biomass production entail a wide variety of management practices that vary by feedstock, climate, soil, and local to regional traditions. Some overarching agronomic management systems and practices that play a key role in biogeochemical cycling include nutrient management systems (organic vs. synthetic fertilizers), tillage, irrigation, monoculture, cover crops and/or crop rotations, and precision agriculture. Each of these system choices affects the soil properties and processes differently.

Cropping systems are typically classed as either organically managed or conventionally managed systems, in which plant nutrients are supplied either by application of municipal waste, green (plant material), or animal manure or by application of synthetic fertilizers. Organic materials can contribute to a long-term increase in soil organic matter (SOM) and associated $\mathrm{C}$, nitrogen $(\mathrm{N})$, phosphorous $(\mathrm{P})$, other macro- and micro-nutrients $(\mathrm{S}, \mathrm{Ca}, \mathrm{Mg}, \mathrm{B}, \mathrm{Cu}$, $\mathrm{Fe}, \mathrm{Cl}, \mathrm{Mn}, \mathrm{Mo}$, and $\mathrm{Zn}$ ), and also improve soil chemical, physical, and biological properties if handled properly. Application of manure is used in modern cropping systems to increase SOM (Edmeades 2003; Tester 1990; Vitosh et al. 1997) and improve soil productivity. In contrast, conventional agricultural cropping systems rely on 
Fig. 2 Climatic zones of the Pan-American region (JRC European Soil Portal 2010; Hijmans et al. 2005; Panagos et al. 2012). (Reproduced with permission of European Commission, Joint Research Centre, Land Resource Management Unit)

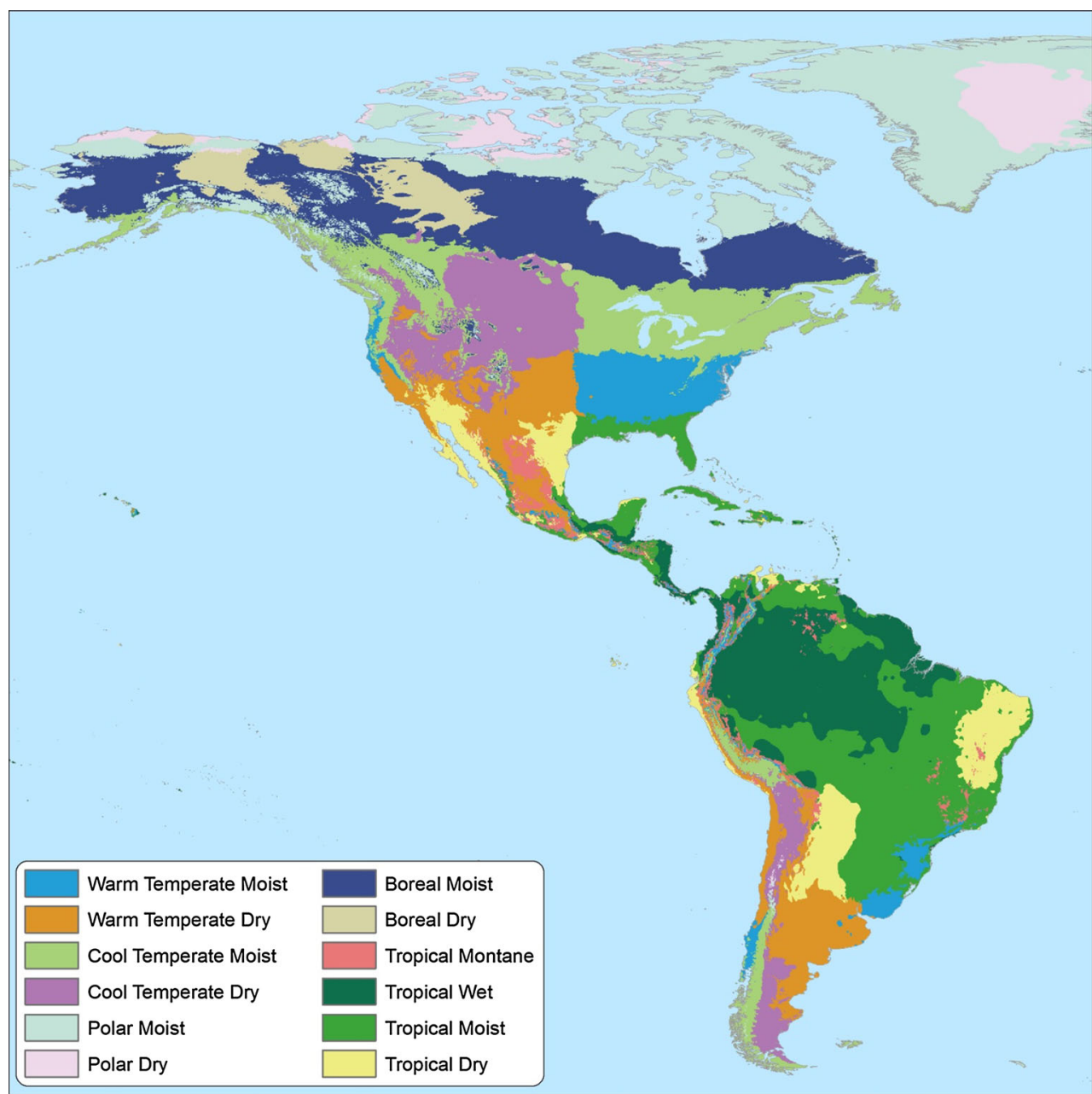

fertilizer; however, these systems also require regular organic inputs from crop residue, root biomass, and rhizodeposition to maintain SOM, soil nutrients, and soil physical properties.

Tillage affects the relative amount of $\mathrm{C}$ derived from aboveground compared to belowground-biomass. In a notillage (NT, one pass direct seeding without previous tillage) system, aboveground biomass will primarily build a duff layer, which reduces soil erosion; only limited amounts of $\mathrm{C}$ will be transported belowground by animal activity and dissolved $\mathrm{C}$ leaching into the soil. In contrast, moldboard plowing buries crop residue (Allmaras et al. 1996; Staricka et al. 1991) and changes the soil structure, which alters the decomposition dynamics (Burgess et al. 2002) and tends to increase decomposition rates. Tillage depth and intensity varies between farms and between regions, depending on tillage implement. Crop residue amount and placement have significant and complex interactions with soil water and thermal regimes, which in turn have important consequences for soil $\mathrm{C}$ dynamics (Power and Doran 1988) and nutrient availability.
Some crop management practices (e.g., irrigation, cover crop, fallow cropping, and crop rotation) depend on total annual precipitation, availability of water source and crop water requirement, and affect crop yield, SOM, and water and nutrient cycling. A cropping system that is viable on one farm or in one region may therefore not be sustainable in another. Management concerns such as plant nutrient level, soil temperature, soil water balance, residue or organic waste inputs, and soil disturbance all interact to control SOM and crop production, which also affects soil organic carbon (SOC, the carbon fraction of SOM). Addition or loss of $\mathrm{C}$ thus affects biomass production.

\section{Forestry}

Forest management also varies in intensity (Stone 1975). Stands can be intensively managed as plantations to increase productivity over shorter time-periods (i.e., rotations) using treatments such as screefing (humus removal), plowing, tilling, burning, planting, herbicide application, fertilization, thinning, and coppicing, some of which are 
similar to treatments used in agriculture. Plantation forestry is common in warm climates with high productivity, such as pine and eucalyptus in the southern US and South America. In contrast, natural forests can be managed with few or no treatments, and harvesting may be accomplished with the aim of emulating natural disturbances. Final felling in both plantations and natural forests can remove all merchantable stems (clearcutting) or only some (selection felling systems). Harvesting residues (tops, branches, foliage) are one of the most readily accessible forest-based biomass sources. On-site residue (trees "processed at stump") can be managed to reduce fire and forest health risks, and to reduce its physical impedance to artificial or natural regeneration by tilling into the mineral soil, physical removal, piling, or prescribed burning. A second entry with equipment is then required to remove residue for bioenergy when it is left on site. In other harvesting systems, whole trees are cut and removed to roadside, where they are de-limbed and tops removed ("processed at roadside"); the harvested residues therefore accumulate off-site and are often burned at roadside if not used for bioenergy. All management practices will affect SOM and nutrient inputs to the site, and can also affect soil physical properties. Unlike agriculture, forest fertilization is not common except in intensively managed plantations. Living tree stems are sometimes used as feedstock, especially if they are removed as unmerchantable thinnings. Dead stems salvaged after natural disturbances can also be used for bioenergy, and can be a potentially larger source of woody biomass than harvesting residue in some regions (Dymond et al. 2010).

\section{Agroforestry}

Agroforestry is the purposeful combining of crops, trees, and sometimes animals on a landscape, and has a long history in Central and South America. Agroforestry systems with a bioenergy component include combinations of traditional agronomic and forestry or SRWC systems, ranging from pine-switchgrass alley cropping in the southeastern US (Albaugh et al. 2012a, b) to the inclusion of bioenergy-specific shrub or tree crops (e.g., jatropha) within the existing cultivated areas (Achten et al. 2010). Many agroforestry practices are similar to traditional agriculture, and use of purposeful combinations of plants can mitigate some negative impacts, and help mitigate climate change (Schoeneberger et al. 2012; Ulloa and Villacura 2005).

\section{Short-Rotation Woody Crops}

Short-rotation woody crops are tree species with potential for high productivity over short-time periods (e.g., eucalypts, poplar, willow). They are grown in intensive agricultural-like systems on either agricultural or forest land, and hence bridge agriculture and forestry. Treatments typically include intensive harvesting and site preparation, rapid-growing plant genotypes, chemical site preparation, herbaceous competition control, and fertilization, resulting in high productivity. Combining SRWC with agroforestry can maximize land use and reduce costs of some chemical and mechanical treatments (e.g., poplar in Chile; Ulloa and Villacura 2005). It is likely that nutrient removals will need to be balanced by nutrient amendments to sustain productivity (Heilman and Norby 1998).

\section{Over-Arching Biogeochemical Cycling Issues}

Biomass feedstock management occurs within the context of a number of anthropogenic pressures that have direct and indirect ramifications on biogeochemical cycling and resultant productivity.

Increased atmospheric $\mathrm{CO}_{2}$ can increase crop growth (Allen 1990; Bazzaz 1990; Ainsworth and Long 2005) and increase storage of $\mathrm{C}$ in soils in tundra (Billings et al. 1984) and other systems (De Graaff et al. 2006) if there are no other limitations to growth; both of these effects can be expected to affect biogeochemical cycling.

Climate change may result in higher air temperatures and alter precipitation patterns, resulting in warmer soil temperatures, greater soil aeration, and higher rates of SOM decomposition (Billings et al. 1984; Oechel and Vourlitis 1995). Photosynthesis and plant growth are generally limited by nutrient availability and soil water content. Elevated temperatures may also modify soil water content and stimulate plant net primary productivity. Soil microorganisms are likely to show an immediate response to higher soil temperature by increasing soil respiration rate, provided that soil water does not become limiting (Giardina and Ryan 2004), and as much as $61 \mathrm{Pg}$ $\left(\mathrm{Pg}=10^{15} \mathrm{~g}\right) \mathrm{C}$ may be respired from the global soil pool to the atmosphere by $\sim 2050$ (Jenkinson et al. 1991). Alternatively, higher rates of decomposition may improve nutrient mineralization rates, and increased $\mathrm{N}$ mineralization could support the increased net primary production in response to high $\mathrm{CO}_{2}$. However, it is also possible that losses of $\mathrm{N}$ from soils could increase with greater rates of mineralization. The potential negative feedback of biogeochemical cycles to climate change is unknown, and there are therefore many uncertainties in predicting the long-term effect of potential climate change on SOM/SOC. In addition, there is much uncertainty about climate change effects in the tropics because most research has been conducted in temperate and boreal systems (Wood et al. 2012). Increased precipitation can lead to loss of soil 
fertility through leaching of nutrients, and extreme events can contribute to erosion, loss of water stable aggregates and OM-rich topsoil, which can reduce soil productivity (Gollany et al. 1991, 1992). Extreme drought and wind events may also lead to wind-blown loss of SOM and nutrients associated with clay particles and, in extreme circumstances, to desertification and loss of productive land.

Deposition of compounds released to the atmosphere from the burning of fossil fuels (e.g., $\mathrm{SO}_{\mathrm{x}}, \mathrm{NO}_{\mathrm{x}}$ ) can lead to regional atmospheric deposition (e.g., acidification of precipitation), resulting in increased base cation leaching from the soil (Lawrence et al. 1997). Intensive biomass removals in forestry can also increase soil acidity (Thiffault et al. 2006). The combined effects of atmospheric deposition and biomass removals can therefore pose a serious threat to northeastern US forests (Adams et al. 2000), and may be most significant in areas with low soil weathering rates. Atmospheric deposition and soil weathering rates therefore contribute to the regional context for incremental loss of cations associated with forest biomass removals, although cation leaching losses caused by biomass harvesting may be proportionately much less than those caused by deposition (Thiffault et al. 2007). However, a local management decision to leave residue on site to reduce acidification and conserve soil cations in areas where this is the main cause of soil cation depletion, or in areas where aquatic systems are readily affected by these depletions (Jeziorski et al. 2008, 2015), may be economically and socially easier to implement than regional reductions in atmospheric deposition. Conversely, atmospheric deposition can also cause $\mathrm{N}$-enrichment (Aber et al. 2003), which in turn can cause other nutrients to become limiting to tree growth; however, removing forest residue for bioenergy can reduce this excess N (Lundborg 1997).

In agriculture, soil acidification can restrict crop growth and favor growth of acid-tolerant plants. Soil acidification from long-term $\mathrm{N}$ fertilization in soils with low SOM can also lead to silica solubilization and movement within the soil profile, forming a layer that impedes water movement and root penetration into the profile (Gollany et al. 2005, 2006).

Nutrient scarcity concerns have arisen, especially for $\mathrm{P}$ ("peak P"; Cordell et al. 2009), because P, K, and even Ca reserves are finite, based on current mining and fertilizer production technologies. The need for nutrient conservation may increase the pressure to leave biomass on site in the future to retain $\mathrm{P}$ and $\mathrm{K}$, especially if bioenergy is considered less of a long-term priority than food crop and stemwood production. This may lead to new ways to valorize and recover scarce minerals exported from sites in biomass.

Land use and land cover change (LULCC) is the human modification of land due to a change in management or vegetation. Changes from natural to agricultural or commercial forest systems have occurred for decades or even to millennia ago, and hence impacts of some level of past, present, or future change is inherent in all managed land, regardless of whether it is used for bioenergy feedstock production or not $(<1 \%$ of global agricultural land is used for biofuel production; Berndes et al. 2010). Impacts of change arising from bioenergy feedstock production may range from negligible in some ecosystems (e.g., minor crop changes on agricultural land) to substantial and with global consequences in others (e.g., conversion of native forests, especially tropical forested peatlands). In addition, some indirect conversion of primary forests for agriculture can take place if traditional crops are displaced elsewhere by new bioenergy crops (Magrin et al. 2014).

These changes can affect hydrology, desertification, biodiversity, and human health (DeFries et al. 2004). However, an increase in GHG emissions is perhaps the most important impact (Gelfand et al. 2011) because net reduction of GHGs is a key rationale for bioenergy use. The production of GHGs following LULCC can be large; for example, the $\mathrm{CO}_{2}$ released to the atmosphere from LULCC in the tropics is $1.1 \pm 0.3 \mathrm{Pg}\left(1 \mathrm{Pg}=10^{15} \mathrm{~g}\right) \mathrm{C} / \mathrm{y}$ (Achard et al. 2004), which is equivalent to 12-20\% of global human-induced GHG emissions (Don et al. 2011). This important and specific aspect of LULCC is addressed in detail later within the context of SOC and GHG emissions. Bioenergy feedstock production is not the only cause of LULCC, which also takes place for food production, creation of forest plantations for traditional products, and infrastructure.

On the other hand, dedicated biomass crops are sometimes well suited for highly erodible and marginal lands, and for replacing annual crops where production is inefficient and where it is ecologically beneficial (Paine et al. 1996; Davis et al. 2012). However, meta-analysis of 153 sites afforested with fast-growing tree species showed decreases in soil $\mathrm{C}$ and most nutrients, suggesting caution is required when harvesting biomass (Berthrong et al. 2009); and marginal lands may require heavy fertilization that can cause non-soil-related problems (Wiegmann et al. 2008). Furthermore, not all marginal lands are suitable for bioenergy production because soil erosion can increase on steep slopes if cultivated, and saturated soils can emit high levels of GHG when drained and SOM is oxidized.

Cumulative effects of climate change, $\mathrm{CO}_{2}$ elevation, atmospheric deposition, and other global and regional impacts may generate unforeseen consequences: no single over-arching pressure on its own may preclude sustainable soil management for biomass, but their interaction plus incremental removals of biomass may, in as-yet-unforeseen circumstances, become problematic in the future (Maynard et al. 2014). 


\section{Soils and Biogeochemical Cycling}

Soil, plants, and their environment interact to determine rates of biogeochemical cycling. Soil-related attributes and processes that determine the sustainability of biogeochemical cycling when managing for biomass feedstocks can be broadly grouped as physical, chemical, or biological.

Physical properties that play key roles in soil function include texture, soil aggregate stability, soil bulk density, water holding capacity and storage, infiltration, and erosion. Physical damage to soils can have long-term impacts on sustainability, and can often be reduced through maintenance of an adequate soil cover of dead plant materialsome of which would otherwise be suitable feedstock for bioenergy.

Chemical properties include total soil nutrient content, the rate at which these nutrients are converted to plantavailable forms (mineralization, weathering, and mineral dissolution), the ability of soils to retain mineralized nutrients (adsorption and exchange capacity), and $\mathrm{pH}$-all of which determine the rate at which nutrients are available for plant growth, or lost from the site through leaching or volatilization. Acidity, conductivity, and the exchange properties of organic molecules, inorganic oxides, and clay minerals also play important roles in nutrient cycling processes.

Biological soil processes help to determine decomposition rates of OM (a source of many plant-available nutrients), contribute to beneficial soil physical properties for plant growth, and are key determinants of soil C sequestration potential. Soil biota is therefore a critical component of soils, and most depend on $\mathrm{OM}$ as a source of energy.

Water plays a key role in biogeochemical cycling because nutrient, $\mathrm{C}$, and water cycles are intricately linked (Asbjornsen et al. 2011; LeBauer and Treseder 2008; Wright et al. 2004). The type of biomass production system and specific management practices deployed directly affect both water balance and quality, and water-soil-plant relationships are an important determinant of the sustainability of biomass production. The uptake of nutrients by plants occurs through the sap during transpiration, and if water availability becomes limiting then plant nutrition and growth are both detrimentally affected (Cramer et al. 2009). Different plant species and communities can have highly contrasting water uptake capacities, depending on their particular physiological properties (e.g., rooting patterns, leaf phenology, and water use efficiency) through which they have adapted to climatic conditions, and through complementary and facilitative interactions among species when grown in polycultures (Asbjornsen et al. 2011). These differences affect biogeochemical cycling and affect key ecosystem services, and hence decisions regarding species selection and combinations can provide management opportunities to optimize water-nutrient interactions in biomass production systems.

Finally, although soil chemical, biological, and physical processes (including water availability) together determine nutrient availability for plant uptake and hence site productivity, site productivity alone is not a good indicator of sustainable soil management because a soil can be fertilized to maintain productivity while $\mathrm{OM}$ and biota decrease and soil physical attributes decline. Furthermore, nutrients must be considered collectively and not individually.

\section{Sustainability Issues}

Bioenergy feedstock production must be environmentally, socially, and economically sustainable to reach its full potential. We focus primarily on soil and biogeochemical cycles. Other aspects of sustainability are covered in companion manuscripts within this Special Issue on bioenergy. Based on our review, the removal of biomass for bioenergy raises four key biogeochemical sustainability concerns: (1) impacts on soil properties resulting from reduced SOM, which controls many aspects of water and nutrient cycling; (2) nutrient management issues resulting from reductions in plant-available nutrients (whether in conjunction with SOM reductions or not); (3) on-site physical impacts; and (4) off-site impacts related to GHGs, water quality, and waste disposal. Two additional issues include application of (5) indicators and (6) predictive models to improve land management for production of bioenergy feedstock.

\section{Biomass Management Impacts on Soil Properties}

Removal of biomass and other practices that reduce SOM can have an effect on soil physical, chemical, and biological properties. Soil physical properties such as soil aggregate stability (Hammerbeck et al. 2012; Mahmood-ulHassan et al. 2013; Moebius-Clune et al. 2008; Malhi and Lemke 2007) are especially susceptible to reduced SOM in agriculture, leading to a shift in aggregate size distribution (Hammerbeck et al. 2012; Mahmood-ul-Hassan et al. 2013) and a higher proportion of erodible aggregates (Schoenau and Campbell 1996), and hence soil degradation. On the other hand, returning residue to the soil can result in $6.7 \%$ fewer erodible aggregates $<0.87-\mathrm{mm}$ diameter and $8.6 \%$ more less-erodible $>38.0$-mm diameter aggregates (Malhi and Lemke 2007); even partial stover retention increases aggregate stability and strength, and water repellency (Blanco-Canqui and Lal 2008). There are few comparable 
studies in forestry, but similar results were found after harvesting Pinus elliottii in Argentina: residue removal significantly reduced both soil $\mathrm{C}$ concentrations and mean aggregate diameter (Lupi et al. 2007). Increased erosion from a change in aggregate stability can further reduce the concentration of SOM in surface soils, exacerbating effects. Biomass retention also reduces raindrop impact and minimizes the intensity of freeze-thaw and wind and water erosion by providing cover (Layton et al. 1993; Miner et al. 2013; Williams et al. 2009). Although there is a potential for partial removal of straw from fields without causing erosion, biomass removal to the limit of soil erodability will result in reduction of SOC concentrations (Miner et al. 2013).

Water balance is also affected by biomass removal because of reduction in aggregate size distribution, and increase in soil bulk density can lead to a reduction of water sorption (Blanco-Canqui and Lal 2008). Residue retention can affect water balance by reducing evaporation from the soil surface and increasing snow retention (Buttle and Murray 2011; O'Connell et al. 2004; Sauer et al. 1998). Soil water content can be 1-4\% lower when biomass is removed under conventional tillage (CT, inversion tillage by tillage tools such as moldboard plow or tandem disk), compared to conservation tillage practices (Malhi and Lemke 2007). Most of this change can be attributed to variation in water storage (up to $84 \%$ ) because of reduction in SOM following residue removal (Wilhelm et al. 1986). It was estimated that as much as $75 \%$ of available stover should be left on Ohio fields to avoid the combination of these physical impacts (Blanco-Canqui and Lal 2008). This estimate could be increased when also considering the chemical, biological, crop, management and economic implications of biomass removal. In forestry, physical soil concerns have largely focused on damage to soil if harvesting residue is not available on sensitive sites as a mat or roadbed for extraction equipment (e.g., UK Forestry Commission 2009), and operating standards are often used to help minimize risk of soil degradation (e.g., BC Ministry of Forests 1999).

Soil biota (along with OM quality, temperature and moisture) drive decomposition processes, which release nutrients from senescent plant tissue. Plant residue is an essential food source for soil biota. Management practices that retain $\mathrm{OM}$ and maintain healthy soil biotic communities are paramount priorities in sustainable soil management. Reduced SOM can change soil fauna population dynamics by decreasing earthworm populations, reducing fungal growth, and changing microbial community structure and function (Bailey et al. 2002; Blanco-Canqui and Lal 2009a; Karlen et al. 1994). Conversely, soil organism abundance is generally greater near the surface of NT systems because of its general correlation with SOM concentrations (Paustain et al. 1997; Schoenau and Campbell
1996). This results in a combination of better food and water resources because of higher SOM and favorable environmental conditions, such as regulated temperature and improved gas exchange near the surface of the soil. Returning biomass to the soil can also increase microbial activity and biomass $\mathrm{C}, \mathrm{N}$, and P by over $30 \%$ without a measurable increase in SOM concentration (Malhi and Lemke 2007; Powlson et al. 2011).

Soil chemistry changes can arise from direct removals of nutrients stored in biomass or from indirect physical and biological changes, which in turn cause changes in soil chemistry. Even traditional crop management can lead to macronutrient deficiencies, which can be exacerbated with residue removal (Ciampitti and García 2007). Apart from loss of nutrients, biomass removal in agriculture can lead to increased soil temperature and decreased soil water and decomposition rates, which can moderately influence $\mathrm{pH}$, cation exchange capacity (CEC), and electrical conductivity (EC). With residue removal, $\mathrm{pH}$ can increase slightly (Blanco-Canqui and Lal 2009b), decrease slightly (Morachan et al. 1972), or have no change (Karlen et al. 1994), depending on the region and soil type. Changes have also been reported for EC and CEC, and EC has been generally found to increase and CEC to decrease with biomass removal (Blanco-Canqui and Lal 2009b). EC, CEC, and pH have a profound influence on the form and availability of plant nutrient supply, as discussed in the next section. Nutrient availability can be altered because of direct changes in nutrient concentrations and indirect changes in nutrient availability through changes in parameters that affect nutrient cycling. Soil chemistry changes are similar in forestry (Thiffault et al. 2011), where residue removal impacts are exacerbated because nutrient concentrations in foliage and branches are higher than in stems and hence nutrient losses are disproportionately greater (Johnson and Todd 1998).

\section{Biomass Management and Organic Matter and Soil Organic Carbon Stocks}

Plant biomass is a precursor of SOM and associated SOC, and its removal affects soil properties. Maintenance of SOM requires that $\mathrm{C}$ inputs from detritus equal or exceed outputs from soil $\mathrm{CO}_{2}$ efflux, leaching, and soil erosion. Management plays a key role in $\mathrm{C}$ cycling through impacts on soil nutrients, water balance, soil temperature, residue inputs, and soil disturbance. Agricultural site preparation such as tilling and planting can lead to soil aggregate disturbance, soil erosion, and $\mathrm{C}$ losses from ecosystems. Harvesting removes $\mathrm{C}$ inputs and contributes to accelerated soil erosion. These are all important agricultural management considerations, as demonstrated by long-term impacts: SOC has declined by as much as $60 \%$ of original 
1870 values in tall-grass prairie soils in the US (Huggins et al. 1998; Lal et al. 1998; Paustain et al. 1997), and by 20-40\% of original values in semiarid lands (Follett et al. 1997; Janzen et al. 1998; Peterson et al. 1998), resulting in a loss of $5 \mathrm{Pg}\left(\mathrm{Pg}=10^{15} \mathrm{~g}\right)$ of $\mathrm{C}$ from US agricultural soils since cultivation of original native grasslands. However, the adoption of sustainable management practices can maintain or even increase soil $\mathrm{C}$ stocks and fertility, and mitigate emission of GHGs (Barreto et al. 2009; BattleBayer et al. 2010; Sá et al. 2009). Increased SOM and decreased soil erosion were found in large NT areas in Argentina and Brazil, while tilled monocultures decreased SOM (Casas 2006), although effects depend on the soil and crop.

Immediate changes in SOC following LULCC can be very important (Achard et al. 2004; Cerri et al. 2007; Don et al. 2011; Fargione et al. 2008; Gelfand et al. 2011) and are affected by precipitation, temperature, depth, and time since LULCC (Don et al. 2011; Eclesia et al. 2012; MarínSpiotta and Sharma 2013; Poeplau et al. 2011). There are some clear trends in SOC following LULCC in tropical and temperate zones. Generally, SOC is progressively greater in the sequence of cropland, grassland, secondary forest (including plantations), to native forest (Don et al. 2011; Eclesia et al. 2012; Poeplau et al. 2011; Ziegler et al. 2012). However, there are exceptions: conversion of tropical pasture to secondary forest can increase SOC (Don et al. 2011), but conversion to plantations can decrease SOC, especially for conifers as compared to broadleaf species (Guo and Gifford 2002). Also, SOC can be lower in tropical plantations than secondary forests in wet cool regions, but plantation establishment in arid regions can increase SOC (Eclesia et al. 2012; Guo and Gifford 2002; Marín-Spiotta and Sharma 2013).

Impacts of forest residue harvesting on SOC are typically not as great, with meta-analyses showing an average $8 \%$ reduction in SOC stocks, primarily in the forest floor (Nave et al. 2010); however, compared to a control, incrementally removing residue had little overall effect (Johnson and Curtis 2001; Nave et al. 2010), although leaving residue increased SOC (Johnson and Curtis 2001). Intensive forestry can also include a variety of tillage and/ or OM manipulation treatments in addition to residue harvest, such as bedding, ripping, and site preparation burning (with or without biomass harvest) which, as in agriculture, can reduce SOC (Nave et al. 2010).

\section{Biomass Management and Nutrients}

Sources of soil nutrients include atmospheric deposition, $\mathrm{N}_{2}$ fixation by microbes, decomposition of SOM, and mineral weathering. Harvesting has a strong influence on nutrient availability through direct impacts on nutrient outputs from biomass removals, inputs from decomposition, and indirect impacts on soil water and temperature, and microbial substrates. Nutrient stocks can also be reduced by increased erosion (see "On-Site Physical Impacts of Biomass Harvest" section), and increased mineralization of SOM resulting from higher soil temperatures and changes in soil water content (Blanco-Canqui and Lal 2009a).

Nutrient limitations from biomass removals can clearly lead to reduced productivity in some agricultural (Berthrong et al. 2009; Blanco-Canqui and Lal 2009b) and forestry systems (Thiffault et al. 2011; Wall 2012), although growth reductions in forestry can be ephemeral and only occur just before canopy closure (Egnell 2011). It is notable that most longer-term forest growth reductions are found in Europe (Thiffault et al. 2011; Wall 2012), but rarely in South America (Gonçalves et al. 2008) or North America (Fleming et al. 2006; Ponder et al. 2012). However, there are cases when tree growth is unaffected and yet soil or foliar nutrients are reduced (Thiffault et al. 2011), which may be an early indication that available nutrient supply is not adequate for optimal tree growth and continued removal of nutrients in harvesting residue over successive rotations may eventually lead to growth limitations (Kimmins 1974). Caution must also be taken when interpreting tree growth response to increased biomass removals because other resources may limit tree growth more than nutrient availability at different stages of succession; for example, decreases in tree growth on dry, nutrient-poor Californian sites were attributed to increased understory competition on slash-removal treatments that led to reduced soil water availability (Ponder et al. 2012).

Nutritionally limited growth has typically been attributed to just one nutrient ("Law of the Minimum", attributed to Sprengel and popularized by von Liebig), but it is increasingly apparent that stoichiometric nutrient ratios are important in determining productivity (Ptacnik et al. 2005). Many systems are co-limited (Harpole et al. 2011; Vadeboncoeur 2010), and modeling suggests that the Law of the Minimum, while a good first-order approximation, is associated more with infertile systems and co-limitation more with fertile systems, with fertilization causing different responses in each (Ågren et al. 2012).

Harvesting of biomass results in a concomitant removal of the nutrients required for future growth, and hence a reduction in soil nutrient stocks. Stover removal compared to harvesting only maize grain increased loss of nutrients (Wilhelm et al. 2010), and this can be dependent on season, water management, and percentage of residue harvested (Karlen et al. 1994). Similarly, cutting plants just below the ear increases losses compared to harvesting only the grain (Hoskinson et al. 2007). Conversely, residue retention can increase uptake of soil P (Schoenau and Campbell 1996). 
There is a greater nutrient loss when forestry residue is removed (Johnson and Todd 1998), and geographic location, species (Johnson et al. 1982), and timing of removal can have distinct and important effects on the mechanisms that control nutrient loss and availability. Impacts may become more evident after several rotations of agricultural or forestry crops if times are shorter than those required for "ecological rotations" (Kimmins 1974) in which nutrients and OM lost at harvesting are replenished.

Site productivity is most commonly limited by $\mathrm{N}$ (LeBauer and Treseder 2008; Vitousek and Howarth 1991), and growth reductions after biomass harvesting in northern forests are often attributed to N limitations (Egnell 2011; Wall 2012). However, $\mathrm{N}$ limitation is predicted to increase as atmospheric $\mathrm{CO}_{2}$ levels increase (Wang and Houlton 2009). This is because it is not just the total amount of soil $\mathrm{N}$ that determines availability, but also $\mathrm{C}: \mathrm{N}$ ratios of decomposing SOM which help determine microbial activity and hence $\mathrm{N}$ mineralization and availability. Decomposition processes will reduce $\mathrm{C}$ over time in the absence of fresh detritus inputs, and biomass harvesting will therefore also affect the $\mathrm{C}: \mathrm{N}$ ratio. Removal of large amounts of $\mathrm{C}$ and $\mathrm{N}$ via grain and residue harvest can lead to shifts from net $\mathrm{N}$ immobilization (use of soil $\mathrm{N}$ by soil microorganisms) to $\mathrm{N}$ mineralization, and additions of crop residues with $\mathrm{C}: \mathrm{N}$ ratios greater than 20:1 to agricultural soil will cause net immobilization of available soil $\mathrm{N}$ during the first few weeks of microbial decomposition of the residue (Green and Blackmer 1995). More specifically, a decrease in a bioavailable fraction of SOM, particulate OM, can lead to loss of available nutrients in agricultural systems, reduced SOC, and narrower soil C:N ratios in surface horizons (Hammerbeck et al. 2012). Processes are similar in forestry but threshold $\mathrm{C}: \mathrm{N}$ ratios for mobilization/immobilization are typically greater and decomposition rates are not as rapid: net immobilization of $\mathrm{N}$ can take place in decaying pine litter in the southeastern US over 26 months (Piatek and Allen 2001) to 36 months (Sanchez 2001), suggesting that $\mathrm{N}$ is immobilized in this system for at least $2-3$ years.

Management can also affect soil C:N ratios. Adequate crop rotations and using plants with extensive root biomass (e.g., switchgrass) in a rotation may increase $\mathrm{C}: \mathrm{N}$ ratios, which can alter SOM levels, depending on the management system. In addition, total $\mathrm{N}$ (and $\mathrm{S}$ ) mineralization from OM can increase with biomass returned to soil under conservation tillage (Schoenau and Campbell 1996). On the other hand, forestry treatments that reduce SOM, such as biomass harvesting, or site preparation, often cause reductions in $\mathrm{N}$ mineralization greater than that predicted by changes in soil environment alone (Burger and Pritchett 1984; Li and Allen 2003), although these have rarely been shown to have long-lasting impacts on growth. Where leaching of residual soil $\mathrm{N}$ after grain harvest is of concern, it may be decreased by rapid immobilization of available inorganic soil $\mathrm{N}$ during decomposition of high $\mathrm{C}: \mathrm{N}$ ratio residue (e.g., maize stover, with a $\mathrm{C}: \mathrm{N}$ ratio of $60: 1$ ); but if high $\mathrm{C}: \mathrm{N}$ residue is removed, net mineralization of residual soil $\mathrm{N}$ may increase, leading to $\mathrm{NO}_{3}{ }^{-}$leaching. However, SOM is not always advantageous to plant production. A build-up of SOM on the forest floor in cool and damp climates can actually impede growth by inhibiting decomposition processes and hence nutrient availability (Prescott et al. 2000). Furthermore, the insulating effect of humus on cold soils may limit tree growth (at least in early years) more than any detrimental effects caused by nutrient loss with humus removals (Kranabetter et al. 2006).

While $\mathrm{N}$ is often the major limiting nutrient, $\mathrm{P}$ is also important for agriculture and forestry. Phosphorus limitations are especially important in tropical and semi-tropical regions, where the dominant soil orders by land area are Oxisols and Ultisols. These soils are strongly weathered and low in available nutrients, such as P (Lal 1997). Phosphorous and $\mathrm{K}$ fertilization is a common practice in most crop production systems since deficiency results in crop yield reduction. Stover removal reduced $\mathrm{P}$ by $40 \%$ on a silt loam soil in Ohio (Blanco-Canqui and Lal 2009b). The only forestry trials exhibiting growth reductions after intensive biomass removals in North America are on P-deficient sites in the southeastern states (Scott and Dean 2006). Similarly, it is recommended that residues be retained on coarse-textured forest soils with low $\mathrm{P}$ reserves in Argentina (Lupi et al. 2011).

\section{Nutrient Management}

Off-site nutrients have been added to soils to increase productivity since time immemorial. Animal manures, green manure, bird guano, and ash were used in the preindustrial era, but modern agriculture and intensive forestry depend largely on synthetic $\mathrm{N}$ and mined sources of $\mathrm{P}, \mathrm{K}$, other cations, and trace metals. Appropriate OM retention and NT systems are critical to maintain both OM and nutrients in the soil in all feedstock production systems. While fertilization replaces nutrients removed from sites through harvesting, it does not directly replace OM, although synthetic fertilizers have been found to enhance SOM on some sites by increasing productivity and litter/root return to the soil (Gregorich et al. 1996; Malhi et al. 2006; Sainju 2014; Vance 2000). Site productivity can therefore be maintained or increased with synthetic fertilizers, although forest applications are discouraged in one certification process in a few jurisdictions (Forest Stewardship Council; FSC 2014) and is not permitted as a part of normal forest management activities in another (Ontario, Canada; OMNRF 2015). Addition of ash from combustion of biomass is possible in agriculture and 
forestry (Insam and Knapp 2011) where permitted but there are limitations. Ash lacks $\mathrm{N}$, can be high in metals, and may not be suitable for some sites and applications must be cost-effective.

Optimum fertilization methods in agriculture (Robertson et al. 2013; Snyder et al. 2007, 2009) and forestry (Ingestad 1974) that match supply with demand and take into account soil water and season can help reduce both the use of fertilizers and off-site impacts while increasing productivity. This is especially important for $\mathrm{P}$ conservation, and where eutrophication or $\mathrm{NO}_{\mathrm{x}}$ production is an issue. Use of biochar to sequester $\mathrm{C}$ and improve soil nutrition is also an emerging management possibility (Atkinson et al. 2010; Sohi et al. 2010), but outcomes can be variable, negative impacts are not yet understood (Biederman and Harpole 2013), and a strategic approach is needed to elucidate mechanisms (Jeffery et al. 2011).

\section{On-Site Physical Impacts of Biomass Harvest}

Crop biomass that is properly managed protects soil from wind and water erosion (Laflen and Colvin 1981), reduces raindrop impact which reduces runoff and improves infiltration and precipitation storage (Govaerts et al. 2007; Mohamoud and Ewing 1990; Savabi and Stott 1994), influences radiation balance and energy fluxes, and reduces the rate of evaporation from the soil (Sauer et al. 1996). Reducing residue under NT systems can increase runoff and soil loss (Lindstrom 1986). Sufficient soil cover must be retained to keep soil erosion within tolerance (T) limits (Larson 1979; Nelson 2002). However, current erosion T values do not necessarily provide an adequate level of protection to prevent SOM decrease and yield loss (Mann et al. 2002; Wilhelm et al. 2010). Conversely, large amounts of residue on the soil surface can keep soil cold and wet for a long time in spring in some regions, cause delay in planting (Linden et al. 2000), and be a source of disease and allelopathic effects (Roer et al. 2000). This excess residue could be removed for bioenergy. However, residue production is inadequate even for soil protection in some arid and semiarid regions (Parr and Papendick 1978). Decreases in SOM decrease infiltration and water holding capacity, and increase soil strength, surface crusting, and susceptibility to soil compaction-which generally leads to increased soil bulk density (Soane 1990), and potentially restricted root penetration. A soil strength increase from 0.3 to $1.5 \mathrm{MPa}$ caused a decline in cotton taproot penetration (Taylor and Burnett 1964), while at $2 \mathrm{MPa}$ penetration resistance limited root growth and reduced crop production (Benjamin et al. 2003; da Silva et al. 1994).

Many jurisdictions have best management practices, guidelines, or regulations to protect forest soils from physical damage (erosion, displacement, rutting, compaction) during forest management activities (Archibald et al. 1997). With the incremental removal of biomass, it is recommended that enough biomass be left to create a temporary roadbed for extraction equipment on sensitive sites (UK Forestry Commission 2009). Notwithstanding concerns about soil compaction, results from a Long-Term Soil Productivity (LTSP) field trial network across Canada and the US showed that upper layers in coarse-textured soils recovered within 5 years of treatment but fine-textured soils showed little recovery (Page-Dumroese et al. 2006), and compaction generally increased seedling survival and growth (Fleming et al. 2006), with production increasing on sandy soils while decreasing on compacted clay soils (Powers et al. 2005). Increased survival and growth was attributed to improved soil temperatures and increased seedling $\mathrm{N}$ uptake on some sites, and soil bulk density was rarely increased to a point where root growth might be affected (Fleming et al. 2006). Ten-year LTSP results confirmed that compaction generally increased tree growth on predominantly coarser-textured soils, which was attributed to amelioration of the physical environment rather than nutritional effects or reduced competition (Ponder et al. 2012). The complex and often subtle responses to biomass removal or soil physical disturbance thus suggest a degree of resiliency in many systems to short-term changes, although the full effects over longer time periods are unknown.

\section{Off-Site Impacts}

Biomass production can result in a range of biogeochemical-related off-site impacts that determine whether or not a practice is sustainable. These include eutrophication and sedimentation in aquatic systems, increased GHG emissions because of nutrient and land management practices, and production of waste that requires appropriate disposal.

\section{Greenhouse Gas Emissions}

Reduction of net atmospheric GHGs is the key rationale for use of bioenergy, but management practices and land use changes that release GHGs counteract the benefits of bioenergy (see also "Biomass Management and Organic Matter and Soil Organic Carbon Stocks" section on impacts on SOM that release $\mathrm{CO}_{2}$ ). Regarding management practices, there is a large range in GHG emissions, depending on the management system used (Adler et al. 2007; Denef et al. 2011; Don et al. 2011). No-till management has the potential to reduce GHG emissions (Lemke et al. 1999; Venterea et al. 2005). In a short-term USDA-ARS REAP study, stover removal decreased total $\mathrm{CO}_{2}$ and $\mathrm{N}_{2} \mathrm{O}$ emissions by 4 and $7 \%$, respectively, 
relative to no removal, while soil $\mathrm{CH}_{4}$ flux was not affected by stover removal, and cumulative soil GHG emissions during the growing season varied widely across sites, by management, and by year (Jin et al. 2014). In a 4-year barley (Hordeum vulare L.) study in the Canadian prairie region comparing $\mathrm{CT}$ with $\mathrm{NT}$ and biomass removal with and without $\mathrm{N}$ fertilization, $\mathrm{N}_{2} \mathrm{O}$ emission was higher $\left(398 \mathrm{~g} \mathrm{~N} \mathrm{ha}^{-1}\right)$ in CT than NT (340 $\left.\mathrm{g} \mathrm{N} \mathrm{ha}^{-1}\right)$ and with $\mathrm{N}$ $\left(580 \mathrm{~g} \mathrm{~N} \mathrm{ha}^{-1}\right)$ than without $\mathrm{N}\left(155 \mathrm{~g} \mathrm{~N} \mathrm{ha}^{-1}\right)$ application (Malhi and Lemke 2007; Malhi et al. 2006). Snyder et al. (2009) reviewed GHG literature and concluded that BMPs for fertilizer $\mathrm{N}$ played a large role in minimizing residual soil $\mathrm{NO}_{3}{ }^{-}$, which helped lower the risk of increased $\mathrm{N}_{2} \mathrm{O}$ emissions; and $\mathrm{N}_{2} \mathrm{O}$ emissions depend on fertilizer- $\mathrm{N}$ sources, and site- and weather-specific conditions. Similarly, urea fertilization did not increase net GHG emissions from some forests at a site (Basiliko et al. 2009) or even national level (e.g., Sweden; Sathre et al. 2010). Nutrient management practices (e.g., manuring, fertilization) that increase biomass production without causing detrimental environmental effects contribute to a net increase in SOM content and reduction in atmospheric $\mathrm{CO}_{2}$. In forestry, increased growth of loblolly pine in the SE US was $\sim 26$ times the $\mathrm{C}$ emitted (as $\mathrm{CO}_{2}$ equivalents of GHG emissions) in manufacturing, transport, and application of the fertilizer used (Albaugh et al. 2012a, b).

Land use and land cover change can have major impacts on GHG emissions on some sites, especially if deforestation occurs. Emissions of GHGs from deforestation in Brazil during the early 2000 s were greater than $75 \%$ of national $\mathrm{CO}_{2}$ emissions (Cerri et al. 2007, Nogueira et al. 2015), and then forest conversion decreased to half its previous level by $2008\left(\sim 20,000 \mathrm{~km}^{2}\right.$ year $\left.^{-1}\right)$, but has recently begun to increase again (Hansen et al. 2013; Nogueira et al. 2015). At continental levels, emissions from LULCC in the Americas were about $0.6 \mathrm{Pg}$ C/y by 2005 (almost exclusively from Central and South America); this is equivalent to about $40 \%$ of global LULCC GHG emissions, and $6 \%$ of total global GHG emissions from LULCC, fossil-fuel burning, cement manufacture and gas flaring in 2005 (Figs. 3 and 4; Houghton 2008; Boden et al. 2013).

From a global perspective, palm oil production is causing rapid deforestation in some tropical regions, with the largest losses occurring in Indonesia $\left(20,000 \mathrm{~km}^{2}\right.$ year $^{-1}$ as of 2011-2012: Hansen et al. 2013). It has been estimated that it will take $\sim 320$ years to mitigate the $\mathrm{C}$ lost to the atmosphere using biodiesel produced from soya grown on cleared Amazon rainforests, and $\sim 840$ years using biodiesel from palm oil produced on drained peatlands in SE Asia (Fargione et al. 2008). From a historical perspective, there is some evidence that increased $\mathrm{C}$ sequestration by regenerating vegetation on previously

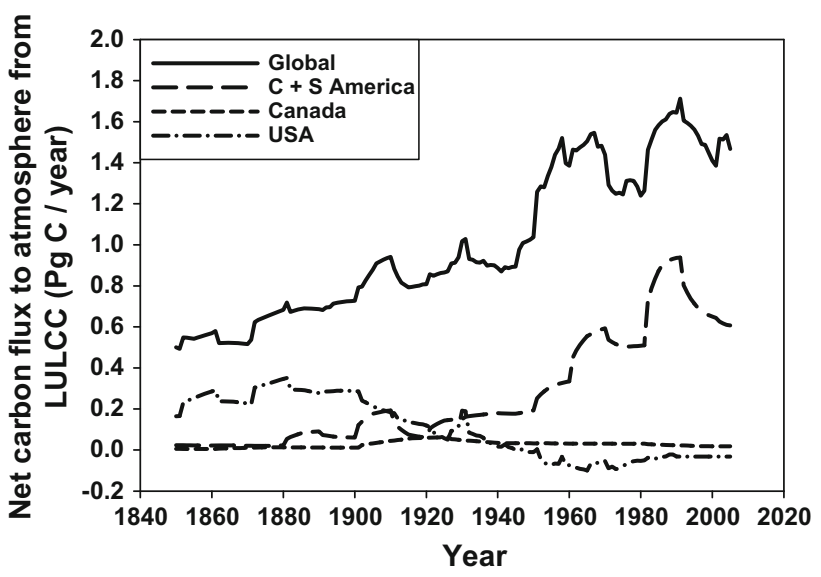

Fig. 3 Total net annual flux of carbon (Pg C/year) to the atmosphere from land use and land cover change (LULCC) globally and in Central and South America $(\mathrm{C}+\mathrm{S}$ Am), Canada and the USA (data from Houghton 2008)

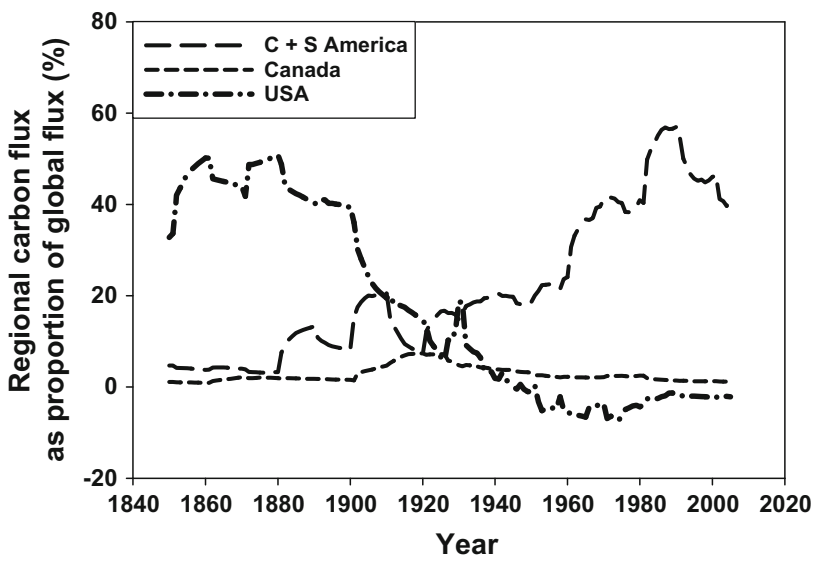

Fig. 4 Net annual flux of carbon to the atmosphere from land use and land cover change (LULCC) in Central and South America $(\mathrm{C}+\mathrm{S}$ Am), Canada and the USA as a proportion (\%) of net annual global flux from LULCC (data from Houghton 2008)

managed land in the Americas (following catastrophic population declines after the arrival of Europeans) contributed to a major decrease in atmospheric $\mathrm{CO}_{2}$, as determined from ice core analysis (Lewis and Maslin 2015). This further emphasizes the measurable impact that LULCC for a range of products, including bioenergy feedstocks, can have on GHGs at a global level.

\section{Eutrophication}

The use of fertilizers and intensive soil management practices is generally greater for annual crops than for woody biomass crops (Dimitriou et al. 2012), and nutrients lost via leaching or surface runoff can affect ground and surface waters and cause downstream eutrophication (Zhou 
et al. 2010). Fertilizer-induced eutrophication has long been recognized as a problem (Bennett et al. 2001) because it can result in blooms of toxic algal species (Correll 1999; Kotak et al. 1994; Lawton and Codd 1991) or oxygen depletion (Anderson et al. 2002) that leads to reduced aquatic biodiversity (Correll 1999). This is driven mostly by $\mathrm{P}$ in freshwater but by $\mathrm{N}$ in marine ecosystems (Conley 2000).

Biomass production systems can contribute to eutrophication: sugarcane production can result in high $\mathrm{N}$ inputs into rivers (Filoso et al. 2003; Gunkel et al. 2007; Martinelli and Filoso 2008); palm oil plantations are particularly fertilizer-intensive and often lead to water contamination (Muyibi et al. 2008); and maize production for bioethanol is a major cause of hypoxic zone expansion in the Gulf of Mexico (Donner and Kucharik 2008). Forest fertilization generally has minor impacts, but in rare circumstances can lead to increased leaching and streamwater concentrations of $\mathrm{N}$ and $\mathrm{P}$ (Binkley et al. 1999).

Optimal fertilization can minimize leaching (Keeney 1982), as can careful manuring, precision agriculture, soil conservation, and implementing best management practices to protect water quality (Ice 2004; Ice et al. 2010; Kleinman 2005; Meals et al. 2010; Power et al. 2001) help to ensure sustainable bioenergy feedstock production. Some bioenergy management systems, especially those using woody crops, can also be used to reduce nutrients leaching into aquatic systems through increasing nutrient uptake and storage and reducing nutrient and sediment losses. Models predict that planting herbaceous perennial bioenergy crops (Miscanthus, switchgrass, or other native prairie grasses) in buffer strips in the Midwestern US can mitigate nutrient losses from intensively managed annual cropping systems (Gopalakrishnan et al. 2009; 2012; Smith et al. 2013; Wu and Liu 2012; Zhou et al. 2010), and buffer strips of switchgrass and SRWC improved the quality of degraded water on marginal lands (Gasparatos et al. 2011; Schmidt-Walter and Lamersdorf 2012). However, converting native grasslands to either switchgrass or Miscanthus production was predicted to increase $\mathrm{NO}_{3}{ }^{-}$load (Wu and Liu 2012). Other studies have documented the role of woody biomass in purifying wastewater (Börjesson and Berndes 2006 in Gasparatos et al. 2011; Kowalik and Randerson 1994) and mitigating soil salinization in dry environments (Harper et al. 2010). Whole-tree harvesting can also remove $\mathrm{N}$-rich biomass in forests with high atmospheric $\mathrm{N}$ deposition (Lundborg 1997), thus reducing $\mathrm{N}$ leaching to aquatic systems.

\section{Waste Disposal at End of Life Cycle}

Off-site impacts are not always negative. Ash from burning biomass is potentially a toxic waste requiring appropriate handling in landfill sites, but can also be used as a fertilizer in both agriculture and forestry on sites where growth is limited by cations, or where increases in $\mathrm{pH}$ increase nutrient availability (Demeyer et al. 2001; Pitman 2006; Vance 1996). Similarly, black C produced through pyrolysis in biofuel production systems can be used to sequester $\mathrm{C}$ in the soil and increase fertility (Atkinson et al. 2010; Sohi et al. 2010), although meta-analyses reveal that results are variable (Biederman and Harpole 2013; Jeffery et al. 2011) and negative impacts are not yet understood (Biederman and Harpole 2013). Nutrients from biogas plants can also be returned to agricultural lands (Hilbert et al. 2014).

\section{Soil Indicators of Sustainability}

Defining the sustainable amount of biomass that can be removed from different sites under different management systems is a key issue. A scientific understanding of this would allow development of meaningful but feasible, economic, and measureable soil and/or site indicators that can be incorporated into management, governance, and marketing systems (e.g., planning tools, guidelines, certification, and regulations), taking into consideration decision, policy, and spatial and temporal contexts (Efroymson et al. 2013; Vance et al. 2014). The few soil indicators proposed to date have yet to be validated across wide ranges of sites, but suggestions include total organic $\mathrm{C}$ and $\mathrm{N}$; extractable $\mathrm{P}$; bulk density; stream concentrations of $\mathrm{NO}_{3}{ }^{-}, \mathrm{P}$ and suspended sediments; GHG emissions; and productivity (McBride et al. 2011). However, indicators may be ecosystem- or species-specific, and total $\mathrm{C}$ from 0 to $20-\mathrm{cm}$ depth in the mineral soil after harvesting, including residue and deadwood, is an excellent predictor of jack pine productivity across a range of site types and treatments in the boreal forest, but not black spruce (Hazlett et al. 2014). Once validated, applying indicators geospatially will help inform management decisions (Kimsey et al. 2011; Thiffault et al. 2014) and allow refinement of biomass inventories and supply chain analyses (e.g., Biomass Siting Analysis Tool-BioSAT (Perdue et al. 2011), Biomass Inventory Mapping and Analysis Tool-BIMAT (AAFC 2015). Appropriate soil indicators may also eventually feed into life cycle assessments (Garrigues et al. 2012; Milài Canals et al. 2007; Oberholzer et al. 2012).

\section{Process-Based Ecosystem Models}

Ecosystem process-based models are valuable tools for synthesizing biogeochemical cycles and can be used to address environmental and management challenges, and to predict the long-term effects of land use and management practices on soil properties and productivity when 
extensive data collection is cumbersome, costly, or impossible. Long-term trends ( $>50$ years) may be quite different from results obtained from short duration (1-5 years) field plot studies (Gollany et al. 2012). Models can rapidly evaluate the effect of existing and potential management strategies or climate on SOM stocks, nutrient loss or gain, or erosion on plant growth and productivity. A wide range of ecosystem models exist (Table 1). The most detailed (e.g., NCSWAP, NuCM) tend to be very flexible in their applications but require many inputs, while others are easy to apply but are limited in scope (e.g., CQESTR, NUTREM).

NCSWAP simulates the soil-water-air-plant continuum and computes the dynamics of organic $\mathrm{C}$ and $\mathrm{N}$, ammonium, and nitrate after biomass decomposition, mineralization, immobilization, nitrification and denitrification,

Table 1 Process-based ecosystem models relevant to intensive biomass harvesting

\begin{tabular}{|c|c|}
\hline Model & Description \\
\hline $\begin{array}{l}\text { BIOME- } \\
\text { BGC }\end{array}$ & $\begin{array}{l}\text { The BIOME-BGC (BioGeochemical Cycles) model is a model originally developed } \\
\text { to simulate a forest stand development through a life cycle and ecosystem processes. } \\
\text { The model requires daily climate data, vegetation, and site conditions to estimate } \\
\text { fluxes of } \mathrm{C}, \mathrm{N} \text {, and water through ecosystems }\end{array}$ \\
\hline CQESTR & $\begin{array}{l}\text { CQESTR (sequester) simulates SOC dynamics in agroecosystems up to } 5 \text { layers, and } \\
\text { can perform long-term ( }>100 \text { years) simulations. It is sensitive to local soils, } \\
\text { climate, crops, cover crops, crop rotations, tillage systems, and organic } \\
\text { amendments. The model requires number and thickness of soil layers, SOM content } \\
\text { and bulk density of each layer, annual crop inputs, farming management practices, } \\
\text { the average daily air temperature and precipitation }\end{array}$ \\
\hline
\end{tabular}

CENTURY CENTURY simulates $\mathrm{C}$ and nutrient (N, P, S) dynamics for the topsoil through an annual cycle, over time scales of centuries and millennia. Flows of nutrients are controlled by the amount of $\mathrm{C}$ in the various pools and climate and environmental condition for agricultural lands, grasslands, forests, and savannas

DAYCENT DAYCENT is the daily version of the CENTURY, which simulates fluxes of C, nutrients, and trace gases among the atmosphere, soil, and plants. The model is used to investigate how land use and climate change impact plant growth and soil $\mathrm{C}$ and $\mathrm{N}$ fluxes

DNDC

DNDC (DeNitrification-DeComposition) simulates thermodynamic and reaction kinetic processes of $\mathrm{C}, \mathrm{N}$, and water driven by the plant and microbial activities. It predicts plant growth, soil $\mathrm{C}$, trace gas, and $\mathrm{CO}_{2}$ emissions, and nitrate leaching in agroecosystem, forest, wetland, and livestock operation systems

EPIC EPIC (Environmental Policy Integrated Climate) is a terrestrial ecosystem model. It can simulate growth and yield of crops, herbaceous and woody vegetation; water and wind erosion; and the cycling of water, heat, carbon, and nitrogen; and estimate $\mathrm{N}_{2} \mathrm{O}$ flux during denitrification and $\mathrm{N}_{2} \mathrm{O}$ and $\mathrm{NO}$ fluxes during nitrification

APEX APEX (Agricultural Policy/Environmental eXtender) is the watershed version of EPIC. It contains all of the algorithms in EPIC plus algorithms to quantify the hydrological balance at different spatial resolutions under different land covers and land uses

NCSOIL NCSOIL simulates $\mathrm{N}$ and $\mathrm{C}$ transformations in the soil. It computes short-term dynamics of organic $\mathrm{C}$ and $\mathrm{N}$, ammonium, and nitrate after residue decomposition, mineralization, immobilization, nitrification and denitrification, and symbiotic $\mathrm{N}$ fixation

NCSWAP NCSWAP (Nitrogen and Carbon Cycling in Soil, Water, Air and Plants) is a simulation model that integrates water flow dynamics, temperature, solute transport, tillage, crop growth, residue effects, and total and tracer $\mathrm{N}$ and $\mathrm{C}$ transformations. The NCSWAP is a large model encompassing several sub-models including NCSOIL

NUTREM NUTREM is a simplified model of nutrient uptake, relocation, and removal for loblolly pine. It estimates annual nutrient uptake for the major nutrients and total nutrients of the stand

FORECAST FORECAST, the successor to FORCYTE, simulates the impacts of different forest management strategies or other disturbances on long-term site productivity

NuCM The NuCM (Nutrient Cycling Model) is the most detailed processes model for the forest-soil-water system

\section{Key references}

Running (1994), Running and Gower

(1991), Peckham et al. (2013)

Rickman et al. (2002), Liang et al. (2009), Gollany et al. (2012)

Parton (1996), Parton et al. (1996), Paustian et al. (1998)

Del Grosso et al. $(2005,2009)$

Giltrap et al. (2010), Hastings et al. (2010)

Williams et al. (1984), Izaurralde et al. (2006)

Gassman et al. (2010), Williams and Izaurralde (2006)

Molina et al. (1983)

Gollany et al. (2004), Molina et al. (1983, 1997)

Ducey and Allen (2001)

Kimmins et al. (1999), Wei et al. (2000)

Johnson et al. (1995) 
and symbiotic $\mathrm{N}$ fixation (Molina et al. 1983, 1997). It can be used to predict the effect of crop biomass removal on $\mathrm{N}$ leaching and denitrification and demonstrate the importance of site-specific management and decision making; under 30-years simulation scenarios when all maize biomass was returned to the soil, $\mathrm{N}$ leaching was reduced by $18 \%$, but denitrification and potential for release of $\mathrm{N}_{2} \mathrm{O}$ was increased (Gollany et al. 2004).

A simpler model, CQESTR, computes the rate of biological decomposition of crop residue or organic amendments as they convert to SOM, and is sensitive to agricultural management practices such as residue harvest (Gollany et al. 2010, 2011; Liang et al. 2008). Wilhelm et al. (2010) used CQESTR and RUSLE2 models to estimate how soil erosion and SOM requirements could limit the amount of stover that could be collected in a sustainable manner and tested three rates of stover removal with and without annual or perennial cover crops under either CT or NT management scenarios to evaluate how stover harvest and tillage affects amount of stover removal. They showed that harvesting stover at a stubble height of $10 \mathrm{~cm}$ would be sustainable if only soil erosion loss $<\mathrm{T}$ is considered, but when SOC maintenance is included then sustainable stover harvest could take place with NT and collection of stover from only the ear-shank upward $(\sim 60 \mathrm{~cm})$.

Muth et al. (2012) integrated two process-based models (RUSLE2, WEPS) and used the Soil Conditioning Index (SCI) algorithm to evaluate sustainable biomass removal for 3 fields in Iowa. Although the modeling method used was a good approach, the use of SCI to calculate SOC maintenance may lead to unsustainable residue removal decisions for significant portions of fields. Use of a process-based $\mathrm{C}$ model with erosion models may be a more prudent alternative to SCI.

Forestry models encounter the same trade-offs of needing to be as simple as possible but as complex as necessary (Kimmins et al. 2008), and a number of models can be used to simulate effects of intensive biomass crop management and biomass removals in forests. Many models have been developed that predict sustainability or productivity based on soil fertility and site productivity under different regimes of management, climate, and disturbance (Proe et al. 1994). For example, FORECAST (Seely et al. 1999; Wei et al. 2000) and BIOME-BGC (Peckham et al. 2013) have been used to simulate harvest sustainability and provide full-system simulations, although they only address $\mathrm{C}$ and $\mathrm{N}$ dynamics. Other models, such as NUTREM (Ducey and Allen 2001), provide a simple yet complete estimation of nutrient removals from harvesting loblolly pine and can be combined with a simplified ecophysiological growth model such as 3PG (Landsberg et al. 2001) to effectively determine potential sustainability concerns. Finally, a few models simulate belowground processes with high complexity, such as the Nutrient Cycling Model (NuCM) (Johnson et al. 1995), which was used to effectively determine soil chemistry responses to harvesting and other disturbances. A variety of other models and modeling approaches, including linking various process models of aboveground and belowground dynamics, have also been used to address sustainability concerns. Notwithstanding the usefulness of forestry models for comparing different scenarios, extensive validation has yet to take place because empirical data from long-term field trials (e.g., LTSP network) is only now becoming available because of the relatively slow growth rates of trees compared to agricultural crops.

\section{Conclusions and Research Recommendations}

The Americas are an expansive and globally important bioenergy producing region. We reviewed the impacts of biomass removal on the long-term sustainability of biogeochemical processes within the region. We considered the impacts of increasing biomass removals on the chemical, biological, and physical properties and functions of soils, and addressed related hydrology and soil water dynamics that affect biogeochemical cycling. We acknowledged but did not exhaustively examine global and overarching issues, such as increased atmospheric $\mathrm{CO}_{2}$ concentrations, climate change, atmospheric deposition, non-renewable nutrient scarcity, LULCC, and cumulative effects.

We did not examine feedstock sources where the enduse of traditionally grown crops is now bioenergy instead of food, fodder, or fiber, but only considered those where there is an incremental increase in biomass harvesting, and hence $\mathrm{OM}$ and nutrient removals. We also did not consider the domestic use of firewood but focused on increased biomass removals for commercial bioenergy production. The abundance of short-term but lack of long-term studies on soil and biogeochemical impacts precludes formulation of a few simple conclusions, and a list highlighting 21 research gaps and knowledge needs was created (Table 2) based on both the over-arching and the specific soil and biogeochemical issues discussed above.

A number of soil sustainability knowledge gaps related to biomass production need to be addressed, notwithstanding the previous identification of some of these in earlier analyses (e.g., Jemison and Lowden 1974; Rennie 1979; Stone 1979; Titus et al. 2008; Vance et al. 2014). Gaps of particular importance include (1) the continuing (Rennie 1979) universal and fundamental need for sitespecific management knowledge (including amounts of residue to be retained) to ensure soil properties and functions are sustained for all combinations of crops, soils, 
Table 2 Research gaps and knowledge needs, based on discussion of biogeochemical sustainability issues in relevant sections in the text

Research gap
Amount of biomass that needs to be left
(sustainability threshold) to maintain soil properties
and functions, and hence site productivity
Long-term ( $>50$ years in agriculture, multi-rotation
in forestry) impacts of intensive biomass
management and harvesting on soils
Causative linkages between intensive biomass
removals, reductions in soil and plant nutrients, and
reduced growth

Timing and duration of reduced growth in forestry

Nutrient co-limitation

P-deficiency

Impact of SOM on soil aggregate stability

Impact of compaction on growth

Deep (sub-surface) soil processes and functions

Base cation weathering rates (both abiotic and biotic) and availability

Fertilization

Rationale Key references

Universal and fundamental question for all combinations of crops, soils, sites, climates, management systems

Required for site-level guidance, and for maximizing management and harvesting intensity without compromising sustainability

Short-term responses do not necessarily predict longterm responses

The apparent greater impact of forest biomass removals on growth in intensively managed European forests than in North American forests suggests that historical land management may affect intensive harvesting impacts

Linkages in forestry are not always apparent: increased biomass removals may not result in reduced soil nutrients, and reduced soil or plant nutrients do not always result in reduced growth

Loss of productivity can be ephemeral, depending on changes in soil availability and tree demand with succession: do ephemeral events constitute loss of long-term sustainability?

Understanding temporal patterns of impact will allow development of better management options

Increasing evidence that co-limitation can sometimes affect growth

Ensure adequate biomass is retained or compensatory treatments used to address co-limitation

Biomass harvesting decreases forest growth on some P-deficient soils

Knowing thresholds would allow identification of sensitive sites

Evidence exists for agriculture, but little research in forestry

Usually detrimental, but compaction can increase growth on some coarse-textured forest soils: how wide-spread and under what conditions is this effect apparent?

Need to understand effects of soil texture, forest type, amount of slash needed to buffer equipment, initial soil condition, and pre-harvest conditions

Increasingly recognized as important, but relatively little information available on either the spatial distribution of deep soil $\mathrm{C}$ or its cycling in response to feedstock production

Abiotic versus biotic components of weathering and uptake across various geologies and feedstocks are not always well understood

Biological weathering can compensate for increased tree uptake in some cases: can it compensate for cation losses from increased biomass harvesting?

Concern that acid deposition exacerbates biomass harvesting-induced losses in some regions: by how much, and where?

Precision agriculture and forestry to reduce use and minimize nutrient movement to aquatic ecosystems

Low impacts on aquatic systems with forest fertilization, but more research required when aquatic systems are sensitive to small impacts
Gollany et al. (2012),

Thiffault et al. (2011),

Scott et al. (2006)

Thiffault et al. (2011)

Kimmins (1974), Stone

(1979), Egnell (2011)

Vadeboncoeur (2010), Harpole et al. (2011),

Ågren et al. (2012)

Scott and Dean (2006)

Blanco-Canqui and Lal

(2009b), Lupi et al. (2007)

Fleming et al. (2006), Page-

Dumroese et al. (2006),

Ponder et al. (2012)

Follett et al. (2012), Angers and Eriksen-Hamel (2008)

Bélanger et al. (2004),

Jongmans et al. (1997)

Tilman et al. (2002) 
Table 2 continued

\begin{tabular}{|c|c|c|}
\hline Research gap & Rationale & Key references \\
\hline Impacts of biochar on soils & $\begin{array}{l}\text { Outcomes are variable and mechanisms are not fully } \\
\text { understood, especially when impacts are negative }\end{array}$ & $\begin{array}{l}\text { Biederman and Harpole } \\
\text { (2013), Jeffery et al. } \\
\text { (2011) }\end{array}$ \\
\hline $\begin{array}{l}\text { Conservation of/alternatives to increasingly rare } \\
\text { fertilizer nutrients }\end{array}$ & $\begin{array}{l}\text { Known reserves of some key fertilizer nutrients (e.g., } \\
\text { rock P) are limited, and some combination of } \\
\text { conservation/recovery/new sources may be required to } \\
\text { sustain current soil productivity in some systems }\end{array}$ & Cordell et al. (2009) \\
\hline $\begin{array}{l}\text { Soil GHG emissions, especially after compensatory } \\
\text { treatments (fertilization, manure, ashing, biochar) }\end{array}$ & $\begin{array}{l}\text { Limited number of studies, especially in systems other } \\
\text { than traditional agriculture and for gases other than } \\
\mathrm{CO}_{2} \\
\text { Needed to estimate net climate change mitigation effects } \\
\text { of biofuels using LCA that takes land management } \\
\text { into account }\end{array}$ & $\begin{array}{l}\text { Liebig et al. (2005), Del } \\
\text { Grosso et al. (2009), } \\
\text { Robertson et al. (2011) }\end{array}$ \\
\hline Land use and land cover change (LULCC) & $\begin{array}{l}\text { LULCC for bioenergy production not always } \\
\text { differentiated from other causes } \\
\text { Indirect effects need to be identified and estimated }\end{array}$ & \\
\hline $\begin{array}{l}\text { Cumulative effects/interactions between different } \\
\text { disturbances }\end{array}$ & $\begin{array}{l}\text { Combined effects of intensive biomass harvesting with } \\
\text { different environmental disturbances (e.g., increased } \\
\text { atmospheric } \mathrm{CO}_{2} \text {, climate change, atmospheric } \\
\text { deposition, etc) }\end{array}$ & Maynard et al. (2014) \\
\hline $\begin{array}{l}\text { Indicators of sustainable feedstock management } \\
\text { (including sustainable soil management) }\end{array}$ & $\begin{array}{l}\text { Require predictive (sensitive site) and evaluative } \\
\text { (monitoring) indicators of soil sustainability }\end{array}$ & McBride et al. (2011) \\
\hline $\begin{array}{l}\text { Inclusion of soil- and nutrient-related impacts in LCA } \\
\text { (nutrient loss/compensation, soil GHG emissions, } \\
\text { off-site impacts, etc) }\end{array}$ & $\begin{array}{l}\text { Require realistic and meaningful metrics for indicators } \\
\text { of biomass production and harvesting impacts on soil } \\
\text { for LCA } \\
\text { Includes need for on- and off-site impacts of } \\
\text { compensatory treatments (e.g., repeated fertilization, } \\
\text { biochar, manure, ashing) }\end{array}$ & Milài Canals et al. (2007) \\
\hline $\begin{array}{l}\text { Methods for spatial prediction of soil taxonomy, soil } \\
\text { properties, and indicators of sustainability }\end{array}$ & $\begin{array}{l}\text { Many parts of Pan-America lack detailed soil surveys; } \\
\text { validated modeling methods are needed to predict soil } \\
\text { taxonomy and properties, especially to identify } \\
\text { locations of sensitive soils }\end{array}$ & $\begin{array}{l}\text { Scull et al. (2003), Burger } \\
\text { and Kelting (1999), } \\
\text { Thiffault et al. (2014) }\end{array}$ \\
\hline Process-based ecosystem models & $\begin{array}{l}\text { Field trials for generating empirical data on complex } \\
\text { interactions, especially over long time periods, are } \\
\text { expensive to maintain } \\
\text { Modeling, within limitations, offers potential solutions }\end{array}$ & \\
\hline Long-term databases & $\begin{array}{l}\text { Shared access to long-term empirical data to understand } \\
\text { complex integrated issues, and increase data } \\
\text { accessibility for complex analyses, including modeling } \\
\text { (calibration, validation), spatial analyses and LCA }\end{array}$ & $\begin{array}{l}\text { USDA ARS (2015), Del } \\
\text { Grosso et al. (2013) }\end{array}$ \\
\hline
\end{tabular}

sites, climates, and management systems; (2) the need for long-term trials (Fig. 5) because short-term effects do not always predict long-term effects (Scott et al. 2006); and (3) the lack of studies on cumulative effects on soils and biogeochemical processes (Maynard et al. 2014), even though a number of global change influences are having, and will increasingly have, inevitable impacts on soil processes.

Within this context, it is important that reviews, syntheses and meta-analyses be used strategically to capitalize on past research investments, not only for the synergy they bring to knowledge generation, but also because they can (1) challenge conventional thinking (e.g., compaction; Fleming et al. 2006) or (2) show that emerging and promising practices may not have the universal effects that were initially expected (e.g., biochar; Biederman and Harpole 2013). Long-term field trials are essential, especially when standardized methods and experimental designs are shared within research networks such as USDAARS-REAP in agriculture (Jin et al. 2014), LTSP in forestry (Powers 2006), and CIFOR in short-rotation forestry (Tiarks et al. 1998). However, new sets of trials are also 


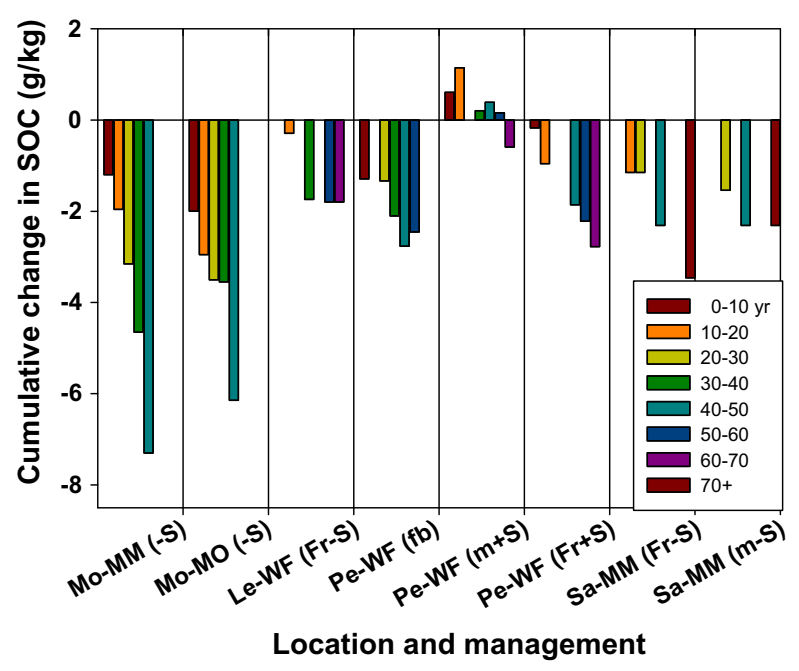

Fig. 5 Decadal cumulative change (loss/accrual) of soil organic carbon (SOC) for eight cropping systems across four long-term experiments in the US and Canada. The first symbol is for experimental site, and the second and third are for continuous maize (MM), maize-oat rotation (MO), and wheat with fallow rotation (WF); the symbols in brackets are for additions of fertilizer $(\mathrm{Fr})$ or manure $(\mathrm{m})$, fall burning $(\mathrm{fb})$, and stover or straw retention $(+\mathrm{S})$ or removal (-S). The eight cropping systems are: (1) Morrow plots (1876) in maize with biomass removed until 1950, Champaign, IL (Darmody and Peck 1997): Mo-MM (-S) continuous maize with stover removal; $M o-M O(-S)$ maize and oat rotation with stover removal; (2) Lethbridge plots (1911) in wheat with straw baled until 1943, Lethbridge, AB (Janzen et al. 1997): Le-WF $(F r-S)$ wheat and fallow rotation with fertilizer $\left(45 \mathrm{~kg} \mathrm{~N} \mathrm{ha}^{-1}\right)$ and straw removal; (3) Pendleton plots (1931) in winter wheat and fallow rotation at Pendleton, OR (Machado 2011; Rasmussen and Albrecht 1998): $P e$ $W F(f b)$ wheat and fallow rotation under fall burn; $P e-W F(m+S)$ wheat and fallow rotation with manure addition $\left(11.2 \mathrm{MT}^{\mathrm{ha}}{ }^{-1}\right.$ year $^{-1}$ ) and straw retention; $\mathrm{Pe}-W F(F r+S)$ wheat and fallow rotation with fertilizer $\left(90 \mathrm{~kg} \mathrm{~N} \mathrm{ha}^{-1}\right)$ and straw retention; and (4) Sanborn Field (1888) in maize with stover removed until 1950, Columbia, MO (Buyanovsky et al. 1997): Sa-MM (Fr-S) continuous maize with fertilization and stover removal; $S a-M M(m-S)$ continuous maize with manure addition $\left(13.4 \mathrm{Mg} \mathrm{ha}^{-1}\right.$ year $^{-1}$ ) and stover removal

needed that take into account emerging knowledge, technologies and treatments, and to ensure that our scientific knowledge can be appropriately integrated into operational policies (Kimmins et al. 2005; Vance et al. 2014). Improved process-based and spatial models are needed that better integrate current knowledge and databases (e.g., USDA ARS 2015, Del Grosso et al. 2013), predict outcomes of different treatments over time, and can be applied at both site and landscape scales. Finally, bioenergy research strategies that are multinational, multiagency, and multidisciplinary are needed to ensure that soil and biogeochemical research takes place effectively and efficiently, as water and atmosphere are covered under a larger environmental and socieconomic context in a way that maximizes its impact across a range of countries, such as those within the Americas.
Acknowledgments The authors gratefully acknowledge support in part by the U.S. National Science Foundation grant CBET-1140152 "RCN-SEES: A Research Coordination Network on Pan American Biofuels and Bioenergy Sustainability". Mention of trade names or commercial products in this publication is solely for the purpose of providing specific information and does not imply recommendation or endorsement by the U.S. Department of Agriculture. USDA is an equal opportunity provider and employer. We thank reviewers for helpful comments and suggestions. This publication is based upon work supported by the U.S. Department of Agriculture-Agricultural Research Service under the ARS-GRACEnet and REAP projects.

\section{References}

AAFC (2015) Agriculture and Agri-Food Canada Biomass Inventory Mapping and Analysis Tool. http://www.agr.gc.ca/atlas/bimat. Accessed 15 April 2015

Aber JD, Goodale CL, Ollinger SV, Smith M-L, Magill AH, Martin ME, Hellett RA, Stoddard JL (2003) Is nitrogen deposition altering the nitrogen status of northeastern forests? Bioscience 53:375-389

Achard F, Eva HD, Mayaux P, Stibig H J, Belward A (2004) Improved estimates of net carbon emissions from land cover change in the tropics for the 1990s. Glob Biogeochem Cycles 18. doi:10.1029/2003GB002142

Achten WMJ, Akinnifesi FK, Maes WH, Trabucco A, Aerts R, Mathijs E, Reubens B, Singh V, Verchot L, Muys B (2010) Jatropha integrated agroforestry systems-biodiesel pathways towards sustainable rural development. In: Ponterio C, Ferra C (eds) Jatropha curcas as a Premier Biofuel: cost, Growth and Management. NOVA Science Publishers, Hauppauge, NY, pp 85-102

Achten MJ, Trabucco A, Maes WH, Verchot LV, Aerts R, Mathijs E, Vantomme P, Singh VP, Muys B (2012) Global greenhouse gas implications of land conversion to biofuel crop cultivation in arid and semi-arid lands-lessons learned from Jatropha. J Arid Environ 98:135-145

Adams MB, Burger JA, Jenkins AB, Zelazny L (2000) Impact of harvesting and atmospheric pollution on nutrient depletion of eastern US hardwood forests. For Ecol Manag 138:301-319

Adler PR, Del Grosso SJ, Parton WJ (2007) Life-cycle assessment of net greenhouse-gas flux for bioenergy cropping systems. Ecol Appl 17:675-691

Ågren GI, Wetterstedt JÅM, Billberger MFK (2012) Nutrient limitation on terrestrial plant growth-modelling the interaction between nitrogen and phosphorus. New Phytol 194:953-960. doi:10.1111/j.1469-8137.2012.04116.x

Ainsworth EA, Long SP (2005) What have we learned from 15 years of free-air $\mathrm{CO}_{2}$ enrichment (FACE)? A meta-analytic review of the responses of photosynthesis, canopy properties and plant production to rising $\mathrm{CO}_{2}$. New Phytol 165:351-372

Albaugh JM, Sucre EB, Leggett ZH et al (2012a) Evaluation of intercropped switchgrass establishment under a range of experimental site preparation treatments in a forested setting on the Lower Coastal Plain of North Carolina, USA. Biomass Bioenergy 46:673-682. doi:10.1016/j.biombioe.2012.06.029

Albaugh TJ, Vance ED, Gaudreault C, Fox TR, Allen HL, Stape JL, Rubilar RA (2012b) Carbon emissions and sequestration from fertilization of pine in the southeastern United States. For Sci $58: 419-429$

Allen LH (1990) Plant responses to rising carbon dioxide and potential interactions with air pollutants. J Environ Qual 19:15-34 
Allmaras RR, Copeland SM, Copeland PJ, Oussible M (1996) Spatial relations between oat residue and ceramic spheres when incorporated sequentially by tillage. Soil Sci Soc Am J 60:1209-1216

Anderson DM, Glibert PM, Burkholder CM (2002) Harmful algal blooms and eutrophication: nutrient sources, composition and consequences. Estuaries 25:704-726

Angers DA, Eriksen-Hamel NS (2008) Full-Inversion tillage and organic carbon distribution in soil profiles: a meta-analysis. Soil Sci Soc Am J 72:1370-1374. doi:10.2136/sssaj2007.0342

Archibald DJ, Wiltshire WB, Morris DM (1997) Forest management guidelines for the protection of the physical environment. Version 1.0. Ontario Ministry of Natural Resources \#51032, ISBN 0-7794-2333-X

Asbjornsen H, Goldsmith GR, Alvarado-Barrientos MS, Rebel K, van Osch FP, Rietkerk M, Chen J, Gotsch S, Tobon C, Geissert DR, Gomez-Tale A, Vache K, Dawson TE (2011) Ecohydrological advances and applications in plant water relations research: a review. J Plant Ecol 4:3-22. doi:10.1093/jpe/rtr005

Atkinson CJ, Fitzgerald JD, Hipps NA (2010) Potential mechanisms for achieving agricultural benefits from biochar application to temperate soils: a review. Plant Soil 337:1-18. doi:10.1007/ s11104-010-0464-5

Bailey VL, Smith JL, Bolton H (2002) Fungal-to-bacterial ratios in soils investigated for enhanced $\mathrm{C}$ sequestration. Soil Biol Biochem 34:997-1007. doi:10.1016/s0038-0717(02)00033-0

Barreto RC, Madari BE, Maddock JEL, Machado PLOA, Torres E, Franchini JC, Costa AR (2009) The impact of soil management on aggregation, carbon stabilization, and carbon loss as $\mathrm{CO}_{2}$ in the surface layer of a Rhodic Ferralsol in Southern Brazil. Agric Ecosyst Environ 132:243-251

Basiliko N, Khan A, Prescott CE, Roy R, Grayston SJ (2009) Soil greenhouse gas and nutrient dynamics in fertilized western Canadian plantation forests. Can J For Res 39:1220-1235

Batjes NH (2009) Harmonized soil profile data for applications at global and continental scales: updates to the WISE database. Soil Use Manag 25:124-127

Battle-Bayer L, Batjes NH, Bindraban PS (2010) Changes in organic carbon stocks upon land use conversion in the Brazilian Cerrado: a review. Agric Ecosyst Environ 137:47-58

Bazzaz FA (1990) The response of natural ecosystems to the rising global $\mathrm{CO}_{2}$ levels. Annu Rev Ecol Syst 21:167-196

B.C. Ministry of Forests (1999) Hazard assessment keys for evaluating site sensitivity to soil degrading processes guidebook, 2nd ed, Version 2.1. For Prac Br, B.C. Min For, Victoria, B.C. Forest Practices Code of British Columbia Guidebook

Bélanger N, Paré D, Bouchard M, Daoust G (2004) Is the use of trees with superior growth a threat to soil nutrient availability? A case study with Norway spruce. Can J For Res 34:560-572

Benjamin JG, Nelson DC, Vigil MF (2003) Quantifying effects of soil conditions on plant growth and crop production. Geoderma 116:137-148

Bennett EM, Carpenter SR, Caraco NF (2001) Human impact on erodable phosphorus and eutrophication: a global perspective. Bioscience 51:227-234

Berndes G, Bird N, Cowie A (2010) Bioenergy, land use change and climate change mitigation. IEA Bioenergy ExCo 2010:3

Berthrong ST, Jobbagy EG, Jackson RB (2009) A global metaanalysis of soil exchangeable cations, $\mathrm{pH}$, carbon, and nitrogen with afforestation. Ecol Appl 19:2228-2241

Biederman L, Harpole WS (2013) Biochar and its effects on plant productivity and nutrient cycling: a meta-analysis. GCB Bioenergy 5:202-214

Billings WD, Peterson KM, Luken JO, Mortensen DA (1984) Interaction of increasing atmospheric carbon dioxide and soil nitrogen on the carbon balance of tundra ecosystems. Oecol $65: 26-29$
Binkley D, Fisher R (2013) Ecology and management of forest soils, 4th edn. Wiley-Blackwell, New York

Binkley D, Burnham H, Allen HL (1999) Water quality impacts of forest fertilization with nitrogen and phosphorus. For Ecol Manag 121:191-213

Blanco-Canqui H, Lal R (2008) Corn stover removal impacts on micro-scale soil physical properties. Geoderma 145:335-346. doi:10.1016/j.geoderma.2008.03.016

Blanco-Canqui H, Lal R (2009a) Crop residue removal impacts on soil productivity and environmental quality. Crit Rev Plant Sci 28:139-163. doi:10.1080/07352680902776507

Blanco-Canqui H, Lal R (2009b) Corn stover removal for expanded uses reduces soil fertility and structural stability. Soil Sci Soc Am J 73:418-426. doi:10.2136/sssaj2008.0141

Boden T, Andres B, Marland G (2013) Global $\mathrm{CO}_{2}$ emissions from fossil-fuel burning, cement manufacture, and gas flaring, 1751-2010. Data at http://cdiac.ornl.gov/ftp/ndp030/global. 1751_2010.ems. Accessed 19 March 2015

Börjesson P, Berndes G (2006) The prospects for willow plantations for wastewater treatment in Sweden. Biomass Bioenergy 30:428-438

Brady NC, Weil RR (2007) The nature and properties of soils, 14th edn. Prentice Hall, Englewood Cliffs, NJ

Burger JA, Kelting DL (1999) Using soil quality indicators to assess forest stand management. For Ecol Manag 122:155-166

Burger JA, Pritchett WL (1984) Effects of clearfelling and site preparation on nitrogen mineralization in a southern pine stand. Soil Sci Soc Am J 48:1432-1437

Burgess MS, Mehuys GR, Madramooto CA (2002) Decomposition of grain-corn residues (Zea mays L.): a litterbag study under three tillage systems. Can J Soil Sci 82:127-138

Buttle JH, Murray CD (2011) Hydrological implications of forest biomass use. Final report prepared for Environment Canada, Ottawa, Canada. August 31, 2011

Buyanovsky GA, Brown JR, Wagner GH (1997) Sanborn field effect of 100 years of cropping on soil parameter. In: Paul EA et al (eds) Soil organic matter in temperate agroecosystems. Longterm experiments in North America. CRC Press, Boca Raton, FL, pp 205-226

Casas (2006) La oportunidad de preservar la calidad y la salud de los suelos http://www.produccion-animal.com.ar/suelos_ganaderos/ 30-preservar_calidad_y_salud_suelos.pdf

Cerri CEP, Sparovek G, Bernoux M, Easterling WE, Melillo JM, Cerri CC (2007) Tropical agriculture and global warming: impacts and mitigation options. Sci Agric 64:83-99

Chum H, Faaij A, Moreira J, Berndes G, Dhamija P, Dong H, Gabrielle B, Goss Eng A, Lucht W, Mapako M, Masera Cerutti O, McIntyre T, Minowa T, Pingoud K (2011) Bioenergy. In: Edenhofer O, Pichs-Madruga R, Sokona Y, Seyboth K, Matschoss P, Kadner S, Zwickel T, Eickemeier P, Hansen G, Schlömer S, von Stechow C (eds) IPCC special report on renewable energy sources and climate change mitigation. Cambridge University Press, Cambridge

Ciampitti IA, García FO (2007) Requerimientos nutricionales, absorción y extracción de macronutrientes y nutrientes secundarios. I Cereales, Oleaginosos e Industriales. Informaciones Agronómicas 33, Archivo Agronómico 11. IPNI Cono Sur. Acassuso, Buenos Aires, Argentina. Disponible en http:// www.ipni.net/ppiweb/ltams.nsf/\$webindex/ E036AC788900A6560325728E0069FF05

Conley DJ (2000) Biogeochemical nutrient cycles and nutrient management strategies. Hydrobiologia 410:87-96

Cordell D, Drangert J-O, White S (2009) The story of phosphorus: global food security and food for thought. Glob Environ 19:292-305. doi:10.1016/j.gloenvcha.2008.10.009

Correll DL (1999) Phosphorus: a rate limiting nutrient in surface waters. Poult Sci 78:674-682 
Cramer MD, Hawkins HJ, Verboom GA (2009) The importance of nutritional regulation of plant water flux. Oecologia 161:15-24

da Silva AP, Kay BD, Perfect E (1994) Characterization of the least limiting water range of soils. Soil Sci Soc Am J 58:1775-1781

Darmody RG, Peck TR (1997) Soil organic changes through time at the university of Illinois Morrow Plots. In: Paul EA et al (eds) Soil organic matter in temperate agroecosystems: long-term experiments in North America. CRC Press, Boca Raton, FL, pp 161-169

Davis SC, Parton WJ, Del Grosso SJ, Keough C, Marx E, Adler PR, DeLucia EH (2012) Impact of second-generation biofuel agriculture on greenhouse-gas emissions in the corn-growing regions of the US. Front Ecol Environ 10:69-74. doi:10.1890/110003

De Graaff MA, Van Groenigen JK, Six J, Hungate B, Van Kessel C (2006) Interactions between plant growth and soil nutrient cycling under elevated $\mathrm{CO}_{2}$ : a meta-analysis. Glob Chang Biol 12:2077-2091

DeFries RS, Asner GP and Houghton RA (eds) (2004) Ecosystems and land use change. American Geophysical Union, Geophysical Monograph Series 153:344. doi:10.1029/GM153

Del Grosso SJ, Mosier AR, Parton WJ, Ojima DS (2005) DAYCENT model analysis of past and contemporary soil $\mathrm{N} 2 \mathrm{O}$ and net greenhouse gas flux for major crops in the USA. Soil Tillage Res 83:9-24. doi:10.1016/j.still.2005.02.007

Del Grosso SJ, Ojima DS, Parton WJ, Stehfest E, Heisteman M, De Angelo B, Rose S (2009) Global scale DAYCENT model analysis of greenhouse gas emissions and mitigation strategies for cropped soils. Global Planet Change 67:44-50. doi:10.1016/j. gloplacha.2008.12.006

Del Grosso SJ, White JW, Wilson G, Vandenberg B, Karlen DL, Follett RF, Johnson JMF, Franzluebbers AJ, Archer DW, Gollany HT, Liebig MA, Ascough J, Reyes-Fox M, Pellack L, Starr J, Barbour N, Polumsky RW, Gutwein M, James D (2013) Introducing the GRACEnet/REAP data contribution, discovery and retrieval system. J Environ Qual 42:1274-1280. doi:10. 2134/jeq2013.03.0097

Demeyer A, Voundi Nkana JC, Verloo MG (2001) Characteristics of wood ash and influence on soil properties and nutrient uptake: an overview. Bioresour Technol 77:287-295

Denef K, Archibeque S, Paustian K (2011) Greenhouse gas emissions from U.S. agriculture and forestry: a review of emissions, sources, controlling factors, and mitigation potential. Interim report to USDA under Contract \#GS-23F-8182H

Dimitriou I, Mola-Yudego B, Aronsson P (2012) Impact of willow short rotation coppice on water quality. Bioenerg Res 5:537-545

Don A, Schumacher J, Freibauer A (2011) Impact of tropical land-use change on soil organic carbon stocks-a meta-analysis. Glob Chang Biol 17:1658-1670

Donner SD, Kucharik CJ (2008) Corn-based ethanol production compromises goal of reducing nitrogen export by the Mississippi river. PNAS 105:4513-4518

Ducey M, Allen HL (2001) Nutrient supply and fertilization efficiency in midrotation loblolly pine plantations: a modeling analysis. For Sci 47(1):96-102

Dymond CD, Titus BD, Stinson G, Kurz WA (2010) Future quantities and spatial distribution of harvesting residue and dead wood from natural disturbances in Canada. For Ecol Manag 260:181-192

Ebermayer E (1876) Die gesamte Lehre der Waldstreu, mit Rücksicht auf die chemische Statik des Waldbaues. [The entire knowledge of forest litter with consideration of chemical data for silviculture. In German.]. Springer, Berlin

Eclesia RP, Jobbagy EG, Jackson RB, Biganzoli F, Piñeiro G (2012) Shifts in soil organic carbon for plantation and pasture establishment in native forests and grasslands of South America. Glob Chang Biol 18:3237-3251
Edmeades DC (2003) The long-term effects of manures and fertilisers on soil productivity and quality: a review. Nutr Cycl Agroecosyst $66: 165-180$

Efroymson RA, Dale VH, Kline KL, McBride AC, Bielicki JM, Smith RL, Parish ES, Schweizer PE, Shaw DM (2013) Environmental indicators of biofuel sustainability: what about context? Environ Manag 51:291-306

Egnell G (2011) Is the site productivity decline in Norway spruce following whole tree harvesting in the final felling in boreal Sweden permanent or temporary? For Ecol Manage 261:148-153

FAO-UNESCO (2007) Digital Soil Map of the World, 2007-02-28, version 3.6. http://www.fao.org/geonetwork/srv/en/metadata.sho w?id=14116. Accessed 30 May 2014

Fargione J, Hill J, Tilman D, Polasky S, Hawthorne P (2008) Land clearing and the biofuel carbon debt. Science 319:1235-1238

Filoso S, Martinelli LA, Williams MR, Lara LB, Krusche A, Ballester MV, Victoria RL, Camargo PB (2003) Land use and nitrogen export in the Piracicaba River basin, Southeast Brazil. Biogeochem 65:275-294

Fleming RL, Powers RF, Foster NW, Kranabetter JM, Scott DA, Ponder F Jr, Berch SM, Chapman WK, Kabzems RD, Ludovici KH, Morris DM, Page-Dumroese DS, Sanborn PT, Sanchez FG, Stone DM, Tiarks AE (2006) Effects of organic matter removal, soil compaction, and vegetation control on 5-year seedling performance: a regional comparison of Long-Term Soil Productivity sites. Can J For Res 36:529-550

Follett RF, Paul EA, Leavitt SW, Halvorson AD, Lyon D, Peterson GA (1997) Carbon isotope ratios of Great Plains soils in wheatfallow systems. Soil Sci Soc Am J 61:1068-1077

Follett RF, Vogel KP, Varvel GE, Mitchell RB, Kimble J (2012) Soil carbon sequestration by switch grass and no-till maize grown for Bioenergy. Bioenergy Res 5:866-875. doi:10.1007/s12155-0129198-y

Forestry Commission UK (2009) Guidance on site selection for brash removal. Forest Research, Forestry Commission, UK

FSC (2014) National Forest Stewardship Standards of the Forest Stewardship Council. https://ic.fsc.org/national-standards.247. htm. Accessed 15 May 2014

Garrigues E, Corsona MS, Angers DA, van der Werf HMG, Walter C (2012) Soil quality in Life Cycle Assessment: towards development of an indicator. Ecol Indic 18:434-442

Gasparatos A, Strombert P, Takeuchi K (2011) Biofuels, ecosystem services and human well-being: putting biofuels in the ecosystem services narrative. Agric Ecosyst Environ 142:111-128

Gassman PW, Williams JR, Wang X, Saleh A, Osei E, Hauck LM, Izaurralde RC, Flowers JD (2010) THE agricultural policy/ environmental extender (APEX) model: an emerging tool for landscape and watershed environmental analyses. ASABE 53:711-740

Gelfand I, Zenone T, Jasrotia P, Chen J, Hamilton SK, Robertson GP (2011) Carbon debt of Conservation Reserve Program (CRP) grasslands converted to bioenergy production. PNAS. doi:10. 1073/pnas.1017277108

Giardina CP, Ryan MG (2004) Evidence that decomposition rates of organic carbon in mineral soil do not vary with temperature. Nature 404:858-861. doi:10.1038/35009076

Giltrap DL, Li CS, Saggar S (2010) DNDC: a process-based model of greenhouse gas fluxes from agricultural soils. Agric Ecosyst Environ 136:292-300

Gollany HT, Schumacher TE, Evenson P, Lindstrom MJ, Lemme GD (1991) Aggregate stability of an eroded and desurfaced Typic Argiustoll. Soil Sci Soc Am J 55:811-816

Gollany HT, Schumacher TE, Lindstrom MJ, Evenson P, Lemme GD (1992) Topsoil depth and desurfacing effects on properties and productivity of a Typic Argiustoll. Soil Sci Soc Am J $56: 220-225$ 
Gollany HT, Molina JAE, Clapp CE, Allmaras RR, Layese MF, Baker JM, Cheng HH (2004) Nitrogen leaching and denitrification in continuous corn as related to residue management. Environ Manag. doi:10.1007/s00267-002.9138-x

Gollany HT, Allmaras RR, Copeland SM, Albrecht SL, Douglas CL $\mathrm{Jr}(2005)$ Tillage and nitrogen fertilizer influences on carbon and soluble silica relations in a Pacific Northwest Mollisol. Soil Sci Soc Am J 69:1102-1109

Gollany HT, Allmaras RR, Copeland SM, Albrecht SL, Douglas CL $\mathrm{Jr}$ (2006) Incorporated source carbon and nitrogen fertilization effects on carbon storage and soluble silica in a Haploxeroll. Soil Sci 171:585-597

Gollany HT, Novak JM, Liang Y, Albrecht SL, Rickman RW, Follett RF, Wilhelm WW, Hunt PG (2010) Simulating soil organic carbon dynamics with residue removal using the CQESTR model. Soil Sci Soc Am J 74:372-383. doi:10.2136/sssaj2009. 0086

Gollany HT, Rickman RW, Liang Y, Albrecht SL, Machado S, Kang S (2011) Predicting agricultural management influence on longterm soil organic carbon dynamics: implications for biofuel production. Agron J103:234-246

Gollany HT, Follett RF, Liang Y (2012) CQESTR simulations of soil organic carbon dynamics. In: Liebig MA, Franzluebbers AJ, Follett RF (eds) Managing agricultural greenhouse gases: coordinated agricultural research through GRACEnet to address our changing climate. Academic Press, San Diego, pp 271-292

Gonçalves JLM, Wichert MCP, Gava JL, Serrano MIP (2008) Soil fertility and growth of Eucalyptus grandis in Brazil under different residue management practices. In: Nambiar EKS (eds) Site management and productivity in tropical plantation forests. Proceedings of workshops in Piracicaba (Brazil) 22-26 November 2004 and Bogor (Indonesia) 6-9 November 2006. Bogor, Indonesia. Center for International Forestry Research (CIFOR)

Gopalakrishnan G, Negri MC, Wang M, Wu M, Snyder SW, Lafreniere L (2009) Biofuels, land, and water: a systems approach to sustainability. Environ Sci Tech 43:6094-6100

Gopalakrishnan G, Negri MC, Salas W (2012) Modeling biogeochemical impacts of bioenergy buffers with perennial grasses for a row-crop field in Illinois. GCB Bioenergy 4:739-750

Govaerts B, Fuentes M, Mezzalama et al (2007) Infiltration, soil moisture, root rot and nematode populations after 12 years of different tillage, residue and crop rotation managements. Soil Tillage Res 94:209-219

Green CJ, Blackmer AM (1995) Residue decomposition effects on nitrogen availability to corn following corn or soybean. Soil Sci Soc Am J 59:1065-1070

Gregorich EG, Ellert BH, Drury CF, Liang BC (1996) Fertilization effects on soil organic matter turnover and corn residue placement. Soil Sci Soc Am J 60:472-476

Gunkel G, Kosmol J, Sobral M, Rohn H, Montenegro S, Aurelian J (2007) Sugarcane industry as a source of water pollution-Case study on the situation in Ipojuca River, Pernambuco, Brazil. Water Air Soil Pollut 180:261-269

Guo LB, Gifford RM (2002) Soil carbon stocks and land use change: a meta analysis. Glob Chang Biol 8:345-360

Hammerbeck AL, Stetson SJ, Osborne SL, Schumacher TE, Pikul JL (2012) Corn residue removal impact on soil aggregates in a notill corn/soybean rotation. Soil Sci Soc Am J 76:1390-1398. doi:10.2136/sssaj2011.0421

Hansen MC, Potapov PV, Moore R et al (2013) High-resolution global maps of 21st-century forest cover change. Sci 342:850-853. doi:10.1126/science. 1244693

Harper RJ, Sochacki SJ, Smettem KRJ, Robinson N (2010) Bioenergy feedstock potential from short-rotation woody crops in a dryland environment. Energy Fuels 24:225-231
Harpole S, Ngai JT, Cleland EE, Seabloom EW, Borer ET, Bracken MES, Elser JJ, Gruner DS, Hillebrand H, Shurin JB, Smith JE (2011) Nutrient co-limitation of primary producer communities. Ecol Let 14:852-862

Hastings AF, Wattenbach M, Eugster W, Li CS, Buchmann N, Smith $P$ (2010) Uncertainty propagation in soil greenhouse gas emission models: an experiment using the DNDC model and at the Oensingen cropland site. Agric Ecosyst Environ 136:97-110

Hazlett PW, Morris DM, Fleming RL (2014) Effect of biomass removals on site carbon and nutrients and jack pine growth in boreal forests. Soil Sci Soc Am J 78:S183-S195

Heilman P, Norby RJ (1998) Nutrient cycling fertility management in temperate short rotation forest systems. Biomass Bioenergy 14:361-370

Hijmans RJ, Cameron SE, Parra JL, Jones PG, Jarvis A (2005) Very high resolution interpolated climate surfaces for global land areas. Int J Climatol 25:1965-1978. http://www.worldclim.org/ current. Accessed 6 June 2014

Hilbert JA, Guerra V, Lopardo NCL (2014) Evolución de la percepción pública de los biocombustibles en Argentina Serie Informes técnicos bioenergía Año 3 Num 52014 ISBN/ISSN 978-987-521-498-9/2250-8481

Hoskinson RL, Karlen DL, Birrell SJ, Radtke CW, Wilhelm WW (2007) Engineering, nutrient removal and feedstock conversion evaluations of four corn stover harvest scenarios. Biomass Bioenergy 31:126-136

Houghton RA (2008) Carbon flux to the atmosphere from land-use changes: 1850-2005. In TRENDS: a compendium of data on global change. Carbon Dioxide Information Analysis Center, Oak Ridge National Laboratory, U.S. Department of Energy, Oak Ridge, Tenn., USA

Huggins DR, Buyanovky GA, Wagner GH, Brown JR, Darmody RG, Peck TR, Lesoing GW, Vanotti MB, Bundy LG (1998) Soil organic $\mathrm{C}$ in the tallgrass prairie-derived region of the cornbelt: effects of long-term crop management. Soil Tillage Res 47:219-234

Ice GG (2004) History of innovative best management practice development and its role in addressing water quality limited waterbodies. J Environ Eng 130:684-689

Ice GG, Schilling E, Vowell J (2010) Trends for forestry best management practices implementation. J For 108:267-273

Ingestad T (1974) Towards optimum fertilization. Ambio 3:49-54

Insam H, Knapp BA (eds) (2011) Recycling of biomass ashes. Springer, New York

IPCC (2011) Summary for Policymakers. In: Edenhofer O, PichsMadruga R, Sokona Y, Seyboth K, Matschoss P, Kadner S, Zwickel T, Eickemeier P, Hansen G, Schlömer S, von Stechow C (eds) IPCC special report on renewable energy sources and climate change mitigation. Cambridge University Press, Cambridge

Izaurralde RC, Williams JR, McGill WB, Rosenberg NJ, Quiroga Jakas MC (2006) Simulation soil C dynamics with EPIC: model description and testing against long-term data. Ecol Model 192:362-384

Janssen R, Rutz DD (2011) Sustainability of biofuels in Latin America: risks and opportunities. Energy Policy 39:5717-5725

Janzen HH, Johnston AM, Carefoot JM, Lindwall CW (1997) Soil organic matter dynamics in long-term experiments in Sothern Alberta. In: Paul EA et al (eds) Soil organic matter in temperate agroecosystems. Long-term experiments in North America. CRC Press, Boca Raton, FL, pp 283-296

Janzen HH, Campbell CA, Izaurralde RC, Ellert BH, Juma NG, McGill WB, Zentner RP (1998) Management effects on soil C storage on the Canadian prairies. Soil Tillage Res 47:181-195 
Jeffery S, Verheijen FGA, van der Velde M, Bastos AC (2011) A quantitative review of the effects of biochar application to soils on crop productivity using meta-analysis. Agric Ecosyst Environ 144:175-187

Jemison GM, Lowden MS (1974) Management and research implications. In: Cramer OP (ed) Environmental effects of forest residues management in the Pacific Northwest-a state-ofknowledge compendium. USDA For Serv Gen Tech Rep PNW24, pp A1-A33

Jenkinson DS, Adams DE, Wild A (1991) Model estimates of $\mathrm{CO}_{2}$ emissions from soil in response to global warming. Nature 351:304-306

Jeziorski A, Yan ND, Paterson AM, DeSellas AM, Turner MA, Jeffries DS, Keller W, Weeber RC, McNicol DK, Palmer ME, McIver K, Arseneau K, Ginn BK, Cumming BF, Smol JP (2008) The widespread threat of calcium decline in fresh waters. Science 322:1374-1377

Jeziorski A, Tanentzap AJ, Yan ND, Paterson AM, Palmer ME, Korosi JB, Rusak JA, Arts MT, Keller W, Ingram R, Cairns A, Smol JP (2015) The jellification of north temperate lakes. Proc R Soc B 282:20142449

Jin VL, Baker JM, Johnson JMF, Karlen DL, Lehman RM, Osborne SL, Sauer TJ, Stott DE, Varvel GE, Venterea RT, Schmer MR, Wienhold BJ (2014) Soil greenhouse gas emissions in response to corn stover removal and tillage management across the US Corn Belt. Bioenergy Res. doi:10.1007/s12155-014-9421-0

Johnson DW (1994) Reasons for concern over impacts of harvesting. In: Dyck WJ, Cole DW, Comerford NB (eds) Impacts of forest harvesting on long-term site productivity. Chapman and Hall, London, pp 1-12

Johnson DW, Curtis PS (2001) Effects of forest management on soil C and N storage: meta analysis. For Ecol Manag 140:227-238

Johnson DW, Todd DE (1998) The effects of harvesting on long-term changes in nutrient pools in a mixed oak forest. Soil Sci Soc Am J 62:1725-1735

Johnson DW, West DC, Todd DE, Mann LK (1982) Effects of sawlog vs whole-tree harvesting on the nitrogen, phosphorus, potassium, calcium budgets of an upland mixed oak forest. Soil Sci Soc Am J 46:1304-1309

Johnson DW, Binkley D, Conklin P (1995) Simulated effects of atmospheric deposition, harvesting, and species change on nutrient cycling in a loblolly pine forest. For Ecol Manag 76:29-45

Jongmans AG, van Breemen N, Lundström U, van Hees PAW, Finlay RD, Srinivasan M, Unestam T, Giesler R, Melkerud P-A, Olsson M (1997) Rock-eating fungi. Nature 389:682-683

JRC European Soil Portal (2010) Climatic zone for Commission Decision of 10 June 2010. http://eusoils.jrc.ec.europa.eu/pro jects/RenewableEnergy/. Accessed 1 May 2014

Karlen DL, Wollenhaupt NC, Erbach DC, Berry EC, Swan JB, Eash NS, Jordahl JL (1994) Crop residue effects on soil quality following 10-years of no-till corn. Soil Tillage Res 31:149-167. doi:10.1016/0167-1987(94)90077-9

Keeney DR (1982) Nitrogen management for maximum efficiency and minimum pollution. In: Stevenson FJ (ed) Nitrogen in agricultural soils. Agron Monogr 22:605-649. doi:10.2134/ agronmonogr22.c16

Kimmins JP (1974) Sustained yield, timber mining and the concept of ecological rotation; a British Columbian view. For Chron 50:27-31

Kimmins JP, Mailly D, Seely B (1999) Modelling forest ecosystem net primary production: the hybrid simulation approach used in FORECAST. Ecol Model 122:195-224

Kimmins JP, Welham C, Seely B et al (2005) Science in forestry: why does it sometimes disappoint or even fail us? Forestry 81:723-734
Kimmins JP, Blanco JA, Seely B, Welham C (2008) Complexity in modeling forest ecosystems; how much is enough? For Ecol Manag 256:1646-1658

Kimsey M Jr, Page-Dumroese D, Coleman M (2011) Assessing bioenergy harvest risks: geospatially explicit tools for maintaining soil productivity in western US Forests. Forests 2:797-813

Kleinman PJA (2005) Phosphorus: agriculture and the environment:1021-1068. doi:10.2134/agronmonogr46.c31

Kotak BG, Prepas EE, Hrudey SE (1994) Blue green algal toxins in drinking water supplies: research in Alberta. Limnol Oceanogr 36:251-267

Kowalik PJ, Randerson PF (1994) Nitrogen and phosphorus removal by willow stands irrigated with municipal waste water-a review of the Polish experience. Biomass Bioenergy 6:133-139

Kranabetter JM, Sanborn P, Chapman BK, Dube S (2006) The contrasting response to soil disturbance between lodgepole pine and hybrid white spruce in subboreal forests. Soil Sci Soc Am J 70:1591-1599

Laflen J, Colvin T (1981) Effect of crop residue on soil loss from continuous row cropping. Trans ASAE 24:605-609

Lal R (1997) Soils of the tropics and their management for plantation forestry. In: Nambiar EKS, and Brown AG (eds) Management of soil, nutrients and water in tropical plantation forests. ACIAR Monograph No. 43, Canberra ACT, Australia, pp xii + 571

Lal R (2005) World crop residues production and implications of its use as a biofuel. Environ Int 31:275-584. doi:10.1016/j.envint. 2004.09.005

Lal R (2007) Biofuel from crop residue. Soil Tillage Res 93:237-238

Lal R, Kimble J, Follett RF, Stewart BA (1998) Soil processes and the carbon cycle. CRC/Lewis Publishers, Boca Raton, FL

Lamers P, Junginger M, Hamelinck C, Faaij A (2012) Developments in international solid biofuel trade-an analysis of volumes, policies, and market factors. Renew Sust Energy Rev 16:3176-3199

Landsberg JJ, Johnsen KH, Albaugh TJ, Allen HL, McKeand SE (2001) Applying 3-PG, a simple process-based model designed to produce practical results, to data from loblolly pine experiments. For Sci 47(1):43-51

Larson WE (1979) Crop residue: energy production or erosion control? Soil Con Soc Am. Special Publication No. 25, Ankeny, IA, $\mathrm{p} 28$

Lawrence GB, David MB, Bailey SW, Shortle WC (1997) Assessment of calcium status in soils of red spruce forests in the northeastern United States. Biogeochemistry 38:19-39

Lawton LA, Codd GA (1991) Cyanobacterial (blue-green algae) toxins and their significance in UK and European waters. J Inst Water Environ Manag 5:460-465

Layton JB, Skidmore EL, Thompson CA (1993) Winter-associated changes in dry-soil aggregation as influenced by management. Soil Sci Soc Am J 57:1568-1572

LeBauer DS, Treseder KK (2008) Nitrogen limitation of net primary productivity in terrestrial ecosystems is globally distributed. Ecology 89:371-379. doi:10.1890/06-2057.1

Lemke RL, Izaurralde RC, Nyborg M, Solberg ED (1999) Tillage and $\mathrm{N}$-source influence soil-emitted nitrous oxide in the Alberta Parkland region. Can J Soil Sci 79:15-24

Lewis SL, Maslin MA (2015) Defining the anthropocene. Nature 519:171-180

Li Q, Allen HL (2003) Nitrogen mineralization dynamics following the establishment of a loblolly pine plantation. Can J For Res 33:364-374

Liang Y, Gollany HT, Rickman RW, Albrecht SL, Follett RF, Wilhelm WW, Novak JM, Douglas CL Jr (2008) CQESTR Simulation of management practice effects on long-term soil organic carbon. Soil Sci Soc Am J 72:1486-1492 
Liang Y, Gollany HJ, Rickman RW, Albrecht SL, Follett RF, Wilhelm WW, Novak JM, Douglas CL Jr (2009) Simulating soil organic matter with CQESTR (v. 2.0): model description and validation against long-term experiments across North America. Ecol Model 220:568-581

Liebig MA, Morgan JA, Reeder JD, Ellert BH, Gollany HT, Schuman GE (2005) Greenhouse gas contributions and mitigation potential of agricultural practices in Northwestern USA and Western Canada. Soil Tillage Res 83:25-52

Linden DR, Clapp CE, Dowdy RH (2000) Long-term corn grain and stover yields as a function of tillage and residue removal in east central Minnesota. Soil Tillage Res 56:167-174

Lindstrom MJ (1986) Effects of residue harvesting on water runoff, soil erosion and nutrient loss. Agric Ecosyst Env 16:103-112

Lowdermilk WC (1953) Conquest of the land through seven thousand years. USDA, SCS Agric. Inform. Bull, p 99

Lundborg A (1997) Reducing the nitrogen load: whole-tree harvesting. A literature review. Ambio 26:387-393

Lupi AM, Conti M, Fernández R, Cosentino D, López G (2007) Efecto de las prácticas de repoblación forestal sobre el carbono orgánico del suelo y la estabilidad de los agregados en el noreste de Argentina. [Effect of reforestation practices on soil organic carbon and aggregate stability in northeastern Argentina. In Spanish with English abstract.] Investigación Agraria: Sistemas y Recursos Forestales 16:230-240

Lupi AM, Aparicio J, Boca T, Díaz D, de los Ángeles García, M, Ingaramo L, Quintero C, Boschetti G (2011) Manejo del fósforo en sitios contrastantes de la región Mesopotámica Argentina bajo uso forestal. [Management of phosphorus in contrasting sites in the Mesopotamian region of Argentina under forestry. In Spanish.] IPNI, Informaciones Agronómicas No. 4:7-13

Machado S (2011) Soil organic carbon dynamics in the Pendleton long-term experiments: implication for biofuel production in Pacific Northwest. Agron J 103:253-260

Mahmood-ul-Hassan M, Rafique E, Rashid A (2013) Physical and hydraulic properties of aridisols as affected by nutrient and cropresidue management in a cotton-wheat system. Acta Sci-Agron 35:127-137. doi:10.4025/actasciagron.v35i1.14683

Malhi SS, Lemke R (2007) Tillage, crop residue and N fertilizer effects on crop yield, nutrient uptake, soil quality and nitrous oxide gas emissions in a second 4-yr rotation cycle. Soil Tillage Res 96:269-283. doi:10.1016/j.still.2007.06.011

Malhi SS, Lemke R, Wang ZH, Chhabra BS (2006) Tillage, nitrogen and crop residue effects on crop yield, nutrient uptake, soil quality and greenhouse gas emissions. Soil Tillage Res 90:171-183. doi:10.1016/j.still.2005.09.001

Mann L, Tolbert V, Cushman J (2002) Potential environmental effects of corn (Zea mays L.) stover removal with emphasis on soil organic matter and erosion. Agric Ecosys Env 89:149-166

Marín-Spiotta E, Sharma S (2013) Carbon storage in successional and plantation forest soils: a tropical analysis. Glob Eco Biogeogr 22:105-117

Magrin GO, Marengo JA, Boulanger JP, Buckeridge MS, Castellanos E, Poveda G, Scarano FR, Vicuña S (2014) Central and South America. In: Barros VR, Field CB, Dokken DJ, Mastrandrea MD, Mach KJ, Bilir TE, Chatterjee M, Ebi KL, Estrada YO, Genova RC, Girma B, Kissel ES, Levy AN, MacCracken S, Mastrandrea PR, White LL (eds) Climate change 2014: impacts, adaptation, and vulnerability. Part B: Regional aspects. Contribution of Working Group II to the Fifth Assessment Report of the Intergovernmental Panel on Climate Change. Cambridge University Press, Cambridge and New York, NY, pp 1499-1566

Martinelli LA, Filoso S (2008) Expansion of sugarcane ethanol expansion in Brazil: environmental and social challenges. Ecol Appl 18:885-898
Maynard DG, Paré D, Thiffault E, Lafleur B, Hogg KE, Kishchuk B (2014) How do natural disturbances and human activities affect soils and tree nutrition and growth in the Canadian boreal forest? Environ Rev 22:161-178

McBride AC, Dale VH, Baskaran LM, Downing ME, Eaton LM, Efroymson RA, Garten CT Jr, Kline KL, Jager HI, Mulholland PJ, Parish ES, Schweizer PE, Storey JM (2011) Indicators to support environmental sustainability of bioenergy systems. Ecol Indic 11:1277-1289

Meals DW, Dressing SA, Davenport TE (2010) Lag time in water quality response to best management practices: a review. J Environ Qual 39:85-96

Milài Canals L, Bauer C, Depestele J, Dubreuil A, Knuchel Freiermuth R, Gaillard G, Michelsen O, Müller-Wenk R, Rydgren B (2007) Key elements in a framework for land use impact assessment within LCA. Int J LCA 12:5-15

Miner GL, Hansen NC, Inman D, Sherrod LA, Peterson GA (2013) Constraints of no-till dryland agroecosystems as bioenergy production ystems. Agron J 105:364-376

Moebius-Clune BN, van Es HM, Idowu OJ, Schindelbeck RR, Moebius-Clune DJ, Wolfe DW, Abawi GS, Thies JE, Gugino BK, Lucey R (2008) Long-term effects of harvesting maize stover and tillage on soil quality. Soil Sci Soc Am J 72:960-969

Mohamoud YM, Ewing LK (1990) Rainfall interception by corn and soybean residue. Trans ASAE 33:507-511

Molina JAE, Clapp CE, Shaffer MJ, Chichester FW, Larson WE (1983) NCSOIL, a model of nitrogen transformations in soil: description, calibration and behavior. Soil Sci Soc Am J 47:85-91

Molina JAE, Crocker GJ, Grace PR, Klír J, Körschens M, Poulton PR, Richter DD (1997) Simulating trends in soil organic carbon in long-term experiments using the NCSOIL and NCSWAP models. Geoderma 81:91-107

Morachan YB, Moldenha WC, Larson WE (1972) Effects of increasing amounts organic residues on continuous corn. 1 . Yields and soil physical properties. Agron J 64:199-203

Muth DJ Jr, McCorkle DS, Koch JB, Bryden KM (2012) Modeling sustainable agricultural residue removal at the subfield scale. Agron J 104:970-981. doi:10.2134/agronj2012.0024

Muyibi SA, Ambali AR, Eissa GS (2008) Development-induced water pollution in Malaysia: policy implications from an econometric analysis. Water Policy 10:193-206

Nave LE, Vance ED, Swanston CW, Curtis PS (2010) Harvest impacts on soil carbon storage in temperate forests. For Ecol Manag 259:857-866

Nelson RG (2002) Resource assessment and removal analysis for corn stover and wheat straw in the Eastern and Midwestern United States-rainfall and wind-induced soil erosion methodology. Biomass Bioenergy 22:349-363

Nogueira EM, Yanai AM, Fonseca FOR, Fearnside PM (2015) Carbon stock loss from deforestation through 2013 in Brazilian Amazonia. Glob Chang Biol 21:1271-1292. doi:10.1111/gcb.12798

O'Connell AM, Grove TS, Mendham DS, Rance SJ (2004) Impact of harvest residue management on soil nitrogen dynamics in Eucalyptus globulus plantations in south western Australia. Soil Biol Biochem 36:39-48

Oberholzer H-R, Freiermuth Knuchel R, Weisskopf P, Gaillard G (2012) A novel method for soil quality in life cycle assessment using several soil indicators. Agron Sustain Dev 32:639-649

Oechel WC, Vourlitis GL (1995) Effects of global change on carbon storage in cold soils. In: Lal $\mathrm{R}$ et al (eds) Soils global change. CRC Press, Boca Raton, Fl, pp 177-187

OMNRF (2015) Forest management guide to silviculture in the Great Lakes-St. Lawrence and Boreal Forests of Ontario. Queen's Printer for Ontario, Toronto, p 394 
Page-Dumroese DS, Jurgensen MF, Tiarks AE, Ponder F Jr, Sanchez FG, Fleming RL, Kranabetter JM, Powers RF, Stone DM, Elioff JD, Scott DA (2006) Soil physical property changes at the North American Long-Term Soil Productivity study sites: 1 and 5 years after compaction. Can J For Res 36:551-564

Paine L, Peterson T, Undersander D, Rineer K, Bartelt G, Temple S, Sample D, Klemme R (1996) Some ecological and socioeconomic considerations for biomass energy crop production. Biomass Bioenergy 10:231-242

Panagos P, Van Liedekerke M, Jones A, Montanarella L (2012) European Soil Data Centre (ESDAC): response to European policy support and public data requirements. Land Use Policy 29:329-338

Parr JF, Papendick RI (1978) Crop residue management systems: New perspectives for soil, water, and energy conservation. Crop residue management systems. ASA Special Publication 31. Oschwald WR, Stelly M, Kral DM and Nauseef JH ASA-CSSASSSA, Inc. Madison, WI

Parton WJ (1996) The CENTURY model. In: Powlson DS, et al (eds) Evaluation of soil organic matter models. NATO ASI Series I, vol 38. Springer, Berlin, pp 283-291

Parton WJ, Ojima DS, Schimel DS (1996) Models to evaluate soil organic matter storage and dynamics. In: Martin RC, Stewart BA (eds) Structure and organic matter storage in agricultural soil. CRC Press, Boca Raton, FL, pp 421-449

Paustain K, Collins HP, Paul EA (1997) Management controls on soil carbon. In: Paul EA, Paustian K, Elliot ET, Cole CV (eds) Soil organic matter in temperate agroecosystems: long-term experiments in North America. CRC Press, Boca Raton, FL, pp $15-49$

Paustian K, Elliot ET, Killian K (1998) Modeling soil carbon in relation to management and climate change in some agroecosystems in Central North America. In: Lal R, Kimble J, Follett RF, Stewart BA (eds) Soil processes and the carbon cycle. CRC/ Lewis Publishers, Boca Raton, FL, pp 459-471

Peckham SD, Perry CH, Wilson BT, Stueve KM (2013) Modeling harvest and biomass removal effects on the forest carbon balance of the Midwest, USA. Environ Sci Policy 25:22-35

Perdue JH, Young TM, Rials TG (2011) The Biomass Site Assessment Tool-BioSAT. Final Report for U.S. Forest Service, Southern Research Station submitted by The University of Tennessee, Knoxville, p 282

Peterson GA, Halvorson AD, Havlin JL, Jones OR, Lyon DJ, Tanaka DL (1998) Reduced tillage and increased cropping intensity in the Great Plains conserves soil C. Soil Tillage Res 47:207-218

Piatek KB, Allen HL (2001) Are forest floors in mid-rotation stands of loblolly pine (Pinus taeda) a sink for nitrogen and phosphorus? Can J For Res 31:1164-1174

Pitman RM (2006) Wood ash use in forestry-a review of the environmental impacts. Forestry 79:563-588. doi:10.1093/for estry/cpl041

Poeplau C, Don A, Vesterdal L, Leifeld J, Van Wesemael BAS, Schumacher J, Gensior A (2011) Temporal dynamics of soil organic carbon after land-use change in the temperate zonecarbon response functions as a model approach. Glob Chang Biol 17:2415-2427

Ponder F, Fleming RL, Berch S, Busse MD, Elioff JD, Hazlett P, Kabzems RD, Kranabetter JM, Morris DM, Page-Dumroese D, Palik BJ, Powers RF, Sanchez FG, Scott DA, Stagg RH, Stone DM, Young DH, Zhang J, Ludovici KH, McKenney DW, Mossa DS, Sanborn PT, Voldseth RA (2012) Effects of organic matter removal, soil compaction and vegetation control on 10th year biomass and foliar nutrition: LTSP continent-wide comparisons. For Ecol Manag 278:35-54

Power JF, Doran JW (1988) Role of crop residue management in nitrogen cycling and use, In: Hargrove WL, et al (eds) Cropping strategies for efficient use of water and nitrogen, Special Publication No. 51. ASA-CSSA-SSSA, Madison, WI, pp 101-113

Power JF, Wiese R, Flowerday D (2001) Managing farming systems for nitrate control: a research review from management systems evaluation areas. J Environ Qual 30:1866-1880. doi:10.2134/ jeq2001.1866

Powers RF (2006) Long-Term Soil Productivity: genesis of the concept and principles behind the program. Can J For Res 36:519-528

Powers RF, Scott DA, Sanchez FG et al (2005) The North American long-term soil productivity experi-ment: findings from the first decade of research. For Ecol Manag 220:31-50

Powlson DS, Glendining MJ, Coleman K, Whitmore AP (2011) Implications for soil properties of removing cereal straw: results from long-term studies. Agron J 103:279-287. doi:10.2134/ agronj2010.0146s

Prescott CE, Maynard DG, Laiho R (2000) Humus in northern forests: friend or foe? For Ecol Manag 133:23-36

Proe MF, Rauscher HM, Yarie J (1994) Computer simulation models and expert systems for predicting productivity decline. In: Dyck WJ, Cole DW (eds) Impacts of forest harvesting on long-term site productivity. Chapman \& Hall, New York, pp 151-186

Ptacnik R, Jenerette GD, Verschoor AM, Huberty AF, Solimini AG, Brookes JD (2005) Applications of ecological stoichiometry for sustainable acquisition of ecosystem services. Oikos 109:52-62

Rasmussen PE, Albrecht SL (1998) Crop management effects on organic carbon in semi-arid Pacific Northwest soils. In: Lal (ed) Management of carbon sequestration in soil. CRC Press, Boca Raton, FL, pp 209-219

REN21 (2014) Renewables 2014 Global Status Report. REN21 (Renewable Energy Policy Network for the 21st Century) Secretariat Paris, France

Rennie PJ (1979) Intensive forest production-nutrient cycling as its key process. In: Leaf AL (ed) Symposium on the impact of intensive harvesting on forest nutrient cycling, U.S. Forest Service N.E. For. Exp. Sta., Bromell, PA; US DOE, fuels from biomass systems; and State University of New York, College of Environmental Science and Forestry, Syracuse, New York, pp 361-365

Rickman R, Douglas C, Albrecht S, Berc J (2002) Tillage, crop rotation, and organic amendment effect on changes in soil organic matter. Environ Pollut 116:405-411

Robertson GP, Hamilton SK, Del Grosso SJ, Parton WJ (2011) The biogeochemistry of bioenergy landscapes: carbon, nitrogen, and water considerations. Ecol Appl 21:1055-1067

Robertson GP, Bruuslsema TW, Gehl RJ, Kanter D, Mauzerall DL, Rotz CA, Williams CO (2013) Nitrogen-climate interaction in US agriculture. Biogeochemistry 114:41-70

Roer JM, Shroyer JP, Paulsen GM (2000) Allelopathy of sorghum on wheat under several tillage systems. Agron J 92:855-860

Running SW (1994) Testing FOREST-BGC ecosystem process simulations across a climatic gradient in Oregon. Ecol Appl $4: 238-247$

Running SW, Gower ST (1991) FOREST-BGC, a general model of forest ecosystem processes for regional applications, II. Dynamic carbon allocation and nitrogen budgets. Tree Physiol 9:147-160

Rutz D, Janssen R, Rogat J, Borch K, Mittelbach M, Schober S, Vos J, Thebaud A, Ballesteros M, Manzanares P, St James C, Coelho ST, Guardabassi P, Aroca G, Soler L, Riegelhaupt E, Arias T, Masera O, Junquera M, Nadal G, Bravo G (2010) Research and technology development cooperation on biofuels between Europe and Latin America. In: Proceedings of the 18th European biomass conference and exhibition, 3-7 May 2010, Lyon, France, pp 2177-2187 
Sá JCM, Cerri CC, Lal R, Dick W, Piccolo MC, Feigl BE (2009) Soil organic carbon and fertility interactions affected by a tillage chronosequence in a Brazilian Oxisol. Soil Tillage Res 104:56-64

Sainju UM (2014) Cropping sequence and nitrogen fertilization impact on surface residue, soil carbon sequestration, and crop yields. Agron J 106:1231-1242

Sanchez FG (2001) Loblolly pine needle decomposition and nutrient dynamics as affected by irrigation, fertilization, and substrate quality. For Ecol Manag 152:85-96

Sathre R, Gustavsson L, Bergh J (2010) Primary energy and greenhouse gas implications of increasing biomass production through forest fertilization. Biomass Bioenergy 34:572-581

Sauer TJ, Hatfield JL, Prueger JH (1996) Corn residue age and placement effects on evaporation and soil thermal regime. Soil Sci Soc J 60:1558-1564

Sauer TJ, Hatfield JL, Prueger JH, Norman JM (1998) Surface energy balance of a corn residue-covered field. Agric For Meteorol 89:155-168

Savabi MR, Stott DE (1994) Plant residue impact on rainfall interception. Trans ASAE 37:1093-1098

Schmidt-Walter P, Lamersdorf NP (2012) Biomass production with willow and poplar short rotation coppices on sensitive areas- the impact on nitrate leaching and groundwater recharge in a dringing water catchment near Hanover, Germany. Bioen Res 5:546-562

Schoenau JJ, Campbell CA (1996) Impact of crop residues on nutrient availability in conservation tillage systems. Can J Plant Sci 76:621-626

Schoeneberger M, Bentrup G, de Gooijer H et al (2012) Branching out: agroforestry as a climate change mitigation and adaptation tool for agriculture. J Soil Water Conserv 67:128A-136A. doi:10.2489/jswc.67.5.128A

Scott DA, Dean TJ (2006) Energy trade-offs between intensive biomass utilization, site productivity loss, and ameliorative treatments in loblolly pine plantations. Biomass Bioenergy 30:1001-1010

Scott DA, Burger JA, Crane B (2006) Expanding site productivity research to sustain non-timber forest functions. For Ecol Manag 227:185-192

Scull P, Franklin J, Chadwick OA, McArthur D (2003) Predictive soil mapping: a review. Prog Phys Geogr 27:171-197

Seely B, Kimmins JP, Welham C, Scoullar K (1999) Management models: defining stand-level sustainability; exploring stand-level stewardship. J For 97:4-10

Smith CM, David MB, Mitchell CA, Masters MD, Anderson-Teixeira KJ, Bernacchi CJ, DeLucia EH (2013) Reduced nitrogen losses after conversion of row crop agriculture to perennial biofuel crops. J Environ Qual 42:219-228

Snyder CS, Bruulsema TW, Jensen TL (2007) Greenhouse gas emissions from cropping systems and the influence of fertilizer management - a literature review. International Plant Nutrition Institute, Norcross, Georgia 25 p

Snyder CS, Bruulsema TW, Jensen TL, Fixen PE (2009) Review of greenhouse gas emissions from crop production systems and fertilizer management effects Ag. Ecosys Environ 133:247-266. doi:10.1016/j.agee.2009.04.021

Soane BD (1990) The role of organic matter in soil compactibility: a review of some practical aspects. Soil Tillage Res 16:179-201

Sohi SP, Krull E, Lopez-Capel E, Bol R (2010) A review of biochar and its use and function in soil. Adv Agron 105:47-82. doi:10. 1016/S0065-2113(10)05002-9

Staricka J, Allmaras RR, Nelson WW (1991) Spatial variation of crop residue incorporation by tillage. Soil Sci Soc Am J $55: 1668-1674$
Stone EL (1975) Soil and man's use of forest land. In: Bernier B, Winget CH (eds) For. Soils For. L. Manag. Proc. Fourth North Am. For. Soils Conf. Les Presses De L'Universite Laval, Laval, Quebec, pp 1-9

Stone EL (1979) Nutrient removals by intensive harvest-some research gaps and opportunities. In: Leaf AL (ed) Symposium on the Impact of Intensive Harvesting on Forest Nutrient Cycling, U.S. Forest Service N.E. For. Exp. Sta., Bromell, PA; US DOE, Fuels from Biomass Systems; and State University of New York, College of Environmental Science and Forestry, Syracuse, New York, pp 366-386

Taylor HM, Burnett E (1964) Influence of soil strength on rootgrowth habits of plants. Soil Sci 98:174-180

Tester CF (1990) Organic amendment effects on physical and chemical properties of a sandy soil. Soil Sci Soc Am J 54:827-831

Thiffault E, Paré D, Bélanger N, Munson A, Marquis F (2006) Harvesting intensity at clear-felling in the boreal forest: impact on soil and foliar nutrient status. Soil Sci Soc Am J 70:691-701

Thiffault E, Bélanger N, Paré D, Hendershot WH, Munson A (2007) Investigating the soil acid-base status in managed boreal forests using the SAFE model. Ecol Model 206:301-321

Thiffault E, Hannam K, Paré D, Titus B, Hazlett P, Maynard D, Brais S (2011) Effects of forest biomass harvesting on soil productivity in boreal and temperate forests-a review. Environ Rev 19:278-309

Thiffault E, Barrette J, Paré D, Titus BD, Keys K, Morris DM, Hope G (2014) Developing and validating indicators of site suitability for forest harvesting residue removal. Ecol Indic 43:1-18

Tiarks A, Nambiar EKS, Cossalter C (1998) Site management and productivity in tropical forest plantations-impacts on soils and options for management over successive rotations. CIFOR Occasional Paper No. 16

Tilman D, Cassman KG, Matson PA, Naylor R, Polasky S (2002) Agricultural sustainability and intensive production practices. Nature 418:671-677

Titus BD, Smith CT, Puddister D, Richardson JR, Young C (2008) Notes from facilitated discussions. Workshop on The Scientific Foundation for Sustainable Forest Biomass Harvesting Guidelines and Policies, Toronto, Ontario, 18-21 Feb 2008, p 48

Troeh FR, Hobbs JA, Donahue RL (1980) Soil and water conservation for Productivity and environmental protection. Prentic-Hall Inc, Englewood Cliffs, New Jersey, p 718

Ulloa J, Villacura L (2005) Contribution of a private poplar industry in Chile to sustainable rural development. Unasylva 221:2-17

USDA ARS (2015) US Department of Agriculture, Agricultural Research Service Data Portal. http://nrrc.ars.usda.gov/arsdatapor tal/\#/Home. Accessed 15 April 2015

Vadeboncoeur MA (2010) Meta-analysis of fertilization experiments indicates multiple limiting nutrients in northeastern deciduous forests. Can J For Res 40:1766-1780. doi:10.1139/ $\mathrm{X} 10-127$

Vance ED (1996) Land application of wood-fired and combination boiler ashes: an overview. J Environ Qual 25:937-944. doi:10. 2134/jeq1996.00472425002500050002x

Vance ED (2000) Agricultural site productivity: principles derived from long-term experiments and their implications for intensively managed forests. For Ecol Manag 138:369-396

Vance ED, Aust WM, Froese RE, Harrison RB, Morris LA (2014) Biomass harvesting and soil productivity: is the science meeting our policy needs? Soil Sci Soc Am J (posted 17 Jan 2014). doi:10.2136/sssaj2013.08.0323

Venterea RT, Burger M, Spokas KA (2005) Nitrogen oxide and methane emissions under varying tillage and fertilizer management. J Environ Qual 34:1467-1477 
Vitosh ML, Lucas RE, Silva GH (1997) Long-term effects of fertilizer and manure on corn yield, soil carbon and other soil chemical properties in Michigan. In: Paul EA et al (eds) Soil organic matter in temperate agroecosystems. CRC Press, Boca Raton, FL, pp 129-139

Vitousek PM, Howarth RW (1991) Nitrogen limitation on land and in the sea: how can it occur? Biogeochemistry 13:87-115. doi:10. 1007/BF0000277

Wall A (2012) Risk analysis of effects of whole-tree harvesting on site productivity. For Ecol Manag 282:175-184

Wang Y-P, Houlton BZ (2009) Nitrogen constraints on terrestrial carbon uptake: implications for the global carbon-climate feedback. Geophys Res Lett 36:L24403. doi:10.1029/ 2009GL041009

Wei X, Liu W, Waterhouse J, Armleder M (2000) Simulations on impacts of different management strategies on long-term site productivity in lodgepole pine forests of the central interior of British Columbia. For Ecol Manag 133:217-229

Wiegmann K, Hennenberg KJ, Fritsche UR (2008) Degraded land and sustainable bioenergy feedstock production. Issue Paper-Joint International Workshop on High Nature Value Criteria and Potential for Sustainable Use of Degraded Lands, Paris, June 30-July 1, 2008

Wilhelm WW, Doran JW, Power JF (1986) Corn and soybean yield response to crop residue management under no-tillage production systems. Agron J 78:184-189

Wilhelm WW, Johnson JMF, Hatfield JL, Voorhees WB, Linden DR (2004) Crop and soil productivity response to corn residue removal: a literature review. Agron J 96:1-17

Wilhelm WW, Hess JR, Karlen DL, Johnson JMF, Muth DJ, Baker JM, Gollany HT, Novak JM, Stott DE, Varvel GE (2010) Review: balancing limiting factors and economic drivers for sustainable Midwestern US agricultural residue feedstock supplies. Indus Biotech 6:271-287
Williams JR, Izaurralde RC (2006) The APEX model. In: Singh VP, Frevert DK (eds) Watershed models. CRC Press, Boca Raton, Fl, pp 437-482

Williams JR, Jones CA, Dyke PT (1984) A modeling approach to determining the relationship between erosion and soil productivity. Trans ASAE 27:129-144

Williams BK, Szaro RC, Shapiro CD (2009) Adaptive Management: The U.S. Department of the Interior Technical Guide. Adaptive Management Working Group, U.S. Department of the Interior, Washington, DC

Wilts AR, Reicosky DC, Allmaras RR, Clapp CE (2004) Long-term corn residue effects: harvest alternatives, soil carbon turnover, and root-derived carbon. Soil Sci Soc Am J 68:1342-1351

Wood TE, Cavaleri MA, Reed SC (2012) Tropical forest carbon balance in a warmer world: a critical review spanning microbialto ecosystem-scale processes. Biol Rev 87:912-927

World Commission on Environment and Development (1987) Our common future. Oxford University Press, Oxford, p 383

Wright IJ, Reich PB, Westoby M, Ackerly DD, Baruch A, Bongers F, Cavender-Bares J, Chapin T, Cornelissen JHC, Diemer M (2004) The worldwide leaf economics spectrum. Nature 428:821-827

Wu Y, Liu SG (2012) Impacts of biofuels production alternatives on water quantity and quality in the Iowa River Basin. Biomass Bioenergy 36:182-191

Zhou X, Helmers M, Asbjornsen H, Kolka R (2010) Perennial strips reduce nitrate levels in soil and shallow groundwater after grassland-to-cropland conversion. J Environ Qual 39:2006-2015

Ziegler AD, Phelps J, Yuen JQ, Webb EL, Lawrence D, Fox JM, Koh LP (2012) Carbon outcomes of major land-cover transitions in SE Asia: great uncertainties and REDD + policy implications. Glob Chang Biol 18:3087-3099 